\title{
Thangmi kinship terminology in comparative perspective
}

\author{
Mark Turin
}

\section{Introduction}

In this article, I describe the largely undocumented kinship terminology of Thangmi (Thāmī in Nepali), a Tibeto-Burman language spoken in central eastern Nepal by the ethnic group of the same name. ${ }^{1}$ Through an analysis of Thangmi kinship terms and the relationships they encode, I draw out a number of structural patterns, which I then compare to other TibetoBurman languages, particularly Kiranti and Newar.

There is no shortage of articles dealing with the kinship structures and terminologies of Nepal's various ethnic groups. The 1970s in particular saw scholars focussing their attention on the topic: In 1974, Victor Doherty studied both Brahmin-Chetri and Gurung kinship, in 1975, Richard Burghart described the role of kinship in Janakpurdham pilgrim groups, and in the same year, Nick Allen published an article on Byansi kinship. A year later, in 1976, Allen analysed Sherpa kinship and in 1977, Shresthacharya offered a topology of Newar kinship. Michael Vinding published a report on the kinship terminologies of ten ethnic groups speaking Bodish languages in 1979, and in 1985, Irene Davids and George van Driem described Limbu kinship terminology. More recently, in 1999, Subhadra Subba Dahal published an incomplete list of Thami kinship terms. ${ }^{2}$

Alongside anthropologists, many linguists working in the Himalayan region have provided diagrams of the kinship terms found in the languages they describe (see van Driem 1993, 1995; Rutgers 1998; Tolsma 1999). The present article is situated within this descriptive tradition of Himalayan linguistics and anthropology.

A word of warning at the outset will remind the reader of the challenges inherent in kinship studies. Bronislaw Malinowski once wrote that "linguistic analysis inevitably leads us into the study of all the subjects covered by Ethnographic field-work" (1945: 302). One such subject is kinship terminology, a topic as much rooted in linguistics as in anthropology. The manner by which people construct and perceive their relationships with others has a direct impact on the words that they use to describe them. The ethno- 
centric nature of kinship studies was not lost on Arthur Hocart, who made the pertinent observation that:

All our difficulties spring from a preconceived idea that kinship terms everywhere try and express the same thing as they do in Aryan ... languages. (1937: 547)

At best, a cogent linguistic analysis of kinship terminology illuminates specific culturally-defined relationships. At worst, the blending of anthropology and linguistics in kinship studies creates a weak mixture of nebulous social observations combined with the impenetrable abbreviations of linguistic code. Hocart's perfect parody of the latter type of analysis warrants citing in full:

A Fijian introduces his wife as wati, so the word is noted as "wife". When it is found that there are hundreds of wati's [sic] who are not his wives, the first translation is not abandoned, but all other uses are explained as extensions: these women, it is explained, are called wives because he might marry any of them if the family so decided; they are wives by anticipation, "potential wives". Upon this muddled lexicography has been built up a whole edifice of primitive promiscuity. (1937: 546)

In an attempt to avoid such difficulties, the present article offers a synchronic analysis of Thangmi kinship terms and then places them in a comparative and historical perspective.

\section{The geographical location of Thangmi dialects and speakers}

Two mutually unintelligible dialects of Thangmi exist, spoken in the Dolakhā and Sindhupālcok districts of Nepal respectively. The dialects differ from one another in terms of phonology, nominal morphology, verbal morphology, and also in lexicon. While a number of the lexical differences can be explained by regular morphophonological alternations, these rules do not account for even half of the differences. The Dolakhā dialect of Thangmi exhibits a more complete verbal agreement system while the Sindhupālcok dialect boasts more complex nominal morphology, particularly for locative suffixes and numeral classifiers. In the present paper, I emphasise the differences between kinship terms in the two dialects. Before turning to the details of these kinship terms, however, the geographical distribution of the speakers must be outlined. 
While the Dolakhā dialect of Thangmi is spoken throughout the central and northern reaches of the district, the Sindhupālcok dialect is spoken only in a handful of villages in the far-eastern valleys of Sindhupālcok. The four villages in which the Sindhupālcok dialect of Thangmi is spoken are flush with the western border of Dolakhā. There is no reason why dialectal differences and isoglosses should necessarily follow the path of political subdivisions and administrative units, but to a greater degree than in many other districts of Nepal, the districts of Dolakhā and Sindhupālcok are separated by a prominent geographical feature: kālincok dẫ $\bar{a}$. This ridge runs north to south, separating the districts from one another, and reaches a maximum elevation of 3,810 metres. While there are many Himalayan ethnic groups for whom such a ridge would pose no obstacle to communication and social interaction, this is not the case for the Thangmi community. There is relatively little intermarriage between the Dolakhā Thangmi and their Sindhupālcok neighbours, and little socio-cultural contact. Generally speaking, it would be fair to say that the Kâlincok ridge effectively prohibits cultural and linguistic exchange.

\section{Thangmi ancestors, clans and marriage rules}

With regard to marriage, the Thangmi practice group-endogamy and clanexogamy, although adherence to the latter is stricter than to the former. Thus, while it is considered wrong to have romantic relations with an opposite sex relative until seven generations have elapsed between consanguineal relatives, sexual relations culminating in marriage with non-Thangmi partners are not taboo. Ethnic group endogamy is preferential rather than prescriptive, while clan endogamy, including sexual relations with crosscousins, is tantamount to incest.

The existence of a set of Thangmi female or women's clans, passed down from mother to daughter, is important. A descent structure for women through female-only clans is rare among the Tibeto-Burman ethnic groups of Nepal, and uncommon elsewhere in Central and South Asia. ${ }^{3}$ Male clan names in the two Thangmi-speaking areas also vary greatly and no single clan has primacy across all dialect boundaries.

According to the Thangmi origin story, the male ancestor, progenitor and forefather of all Thangmi is known as Yalapati Chuku. His omnipresence and importance may explain the existence of both apa 'father' and chuku 'fatherin-law' in his name, two highly distinct kinship roles not readily conflated in 
Thangmi society. Yalapati Chuku is, however, both an apa and a chuku: 'Father' to all Thangmi men and 'father-in-law' to all Thangmi women.

The female Thangmi ancestor is known interchangeably as Sunari Ama and Sunari Aji. She fulfils both the role of 'mother' to all Thangmi women and 'mother-in-law' to all Thangmi men, and in so being is the female ancestor and foremother of all Thangmi. The variation in her second name, ama and aji, parallels that of apa and chuku described above: In Thangmi, ama denotes 'mother' and aji 'mother-in-law'. It should be noted that ama also denotes 'mother' in Nepali and that Thangmi aji agrees with with Classical Newar ajī 'grandmother, paternal or maternal' (Jørgensen 1936: 18) as well as with Hindi $a j \bar{\imath}$ or $\bar{a} j \bar{\imath}$ 'paternal grandmother' (McGregor 2002: 82). ${ }^{4}$

Why are these two ancestors interchangeably referred to as 'parent' and 'parent-in-law'? One explanation may be the existence of separate male and female clans. Most Thangmi are well aware of the explicitly incestuous nature of their origin story and it continues to cause shame and embarrassment to them (Turin 1999: 17). The overtly incestuous account of sibling marriages in the Thangmi origin story may be rationalised by reckoning women's clan allegiance solely in terms of descent from their mothers, and men's clan membership as similarly deriving solely from their fathers. Following this logic, even opposite sex siblings with the same biological parents will never be of the same clan since they inherit their clan identity from their same-sex parents. This has the paradoxical effect of "de-incestuising" sibling unions. Whether female clans were an adaptive reaction to the incestuous backdrop of the Thangmi genesis narrative or whether the existence of female clans made it possible for siblings to marry, thereby not contravening the incest taboo, remains a rhetorical question. ${ }^{5}$

Despite the prohibitions outlined above, most Thangmi men and women appear to be unaware of their clan affiliation. When a wedding is planned, Thangmi ritual practitioners, known locally as guru, ${ }^{6}$ are called to ratify the alliance. In such moments, guru are required to recall the clan memberships of both bride and groom, and function as archivists of oral history and preventers of incest.

\section{Family structure and the spacing of settlements}

Victor Doherty noted the Brahmin-Chetri custom of "spacing homesteads widely rather than grouping houses into a nucleated village with the fields of all the residents surrounding this" (1974: 27) and concluded that "the settlement pattern scatters the members of the society, so do the marriage and kinship rules" (1974: 37). A similar pattern is observable in the Thangmi- 
speaking area: Most houses are built far apart from one another, and each dwelling is surrounded by fields. In Thangmi villages, it is rare to see houses packed close together with arable lands surrounding the entire settlement.

This scattering may be explained in a number of ways. An economically-motivated argument might suggest that Thangmi land holdings are predominantly small (due in part to generations of land exploitation) and that villagers build their homes within the boundaries of their land. This explanation is not sufficient, however, and does not explain why even wealthy Thangmi families with substantial land holdings dispersed across a wide area choose to live far apart from one another. A more convincing explanation lies in the observation that Thangmi households are predominantly nuclear rather than joint: Children leave the parental home to establish independent homes early, and grandparents do not live with their grandchildren. While this is uncommon in hill Nepal, more uncommon still is the practice that when one grandparent dies, the other grandparent continues to live alone and does not move in with one of their children. In the Thangmi-speaking villages of Dolakhā and Sindhupālcok, the majority of Thangmi couples above the age of 55 are self-sufficient and live alone. It is a common sight to see 60 -year old men and women carrying wood, fetching water, tending animals and cooking for themselves. The few immigrants to the area from Nepal's other ethnic groups and castes vocally express their outrage at this cultural practice. In particular, Newars living in otherwise predominantly Thangmi villages are none too impressed by what they see as a flagrant disregard for seniority and age. This opprobrium is of little concern to Thangmi couples, who view nuclear rather than joint families as both a cultural norm and a marker of their ethnic identity.

While it is tempting to map elements of the cultural practices outlined above onto the structures of Thangmi kinship terminology, we must be wary of reductive or causative logic. Nevertheless, I believe that elements of the cultural context of Thangmi familial life may be represented in the linguistic terms used to describe social relationships. As the remainder of this article will show, the Thangmi language does indeed encode a number of kinship relationships in culturally revealing ways.

\section{Representing kinship}

If the aim is to understand the structure of a kinship system through an analysis of the categories denoted by the indigenous terms, a clear crosscultural metalanguage for kinship is needed. 
Over time, certain modes of representing kinship relationships have emerged as de facto standards, ranging from the taxonomical tree-like model with circles and triangles to a list or glossary full of abbreviations (see Vinding 1979: 208-220). In this article, I have opted to represent kinship relationships in both ways, with kinship charts offered as an appendix. First, I present the kinship terminology of Thangmi. Second, I offer a morphemic analysis of elements and components of Thangmi kinship terms. Third and finally, I relate these terms to their Tibeto-Burman etyma and draw some concluding remarks. Table 1 below shows the common abbreviations used for referring to kinship relationships. Abbreviations may be combined to indicate complex relationships.

Table 1. Standard abbreviations used for kinship relationships

\begin{tabular}{llll}
\hline mother & $(\mathrm{M})$ & father & $(\mathrm{F})$ \\
sister & $(\mathrm{Z})$ & brother & $(\mathrm{B})$ \\
daughter & $(\mathrm{D})$ & son & $(\mathrm{S})$ \\
wife & $(\mathrm{W})$ & husband & $(\mathrm{H})$ \\
elder & $(\mathrm{e})$ & younger & $(\mathrm{y})$ \\
\hline
\end{tabular}

e.g. $\quad($ FyZ $)=$ father's younger sister

\section{Thangmi kinship terms}

The Thangmi language differentiates kin on the basis of generation, age within a specific generation, gender, in-law relationships and to a limited extent, kin through sibling relationship versus kin through one's spouse. The gender of the speaker can be a differentiating factor, but not in all situations. There is no single or specific word for 'spouse'.

In addition to distinctions on the basis of generation, Thangmi differentiates on the basis of age within generations by marking the relative age of kin with respect to the speaker. Table 2 below presents the Thangmi sibling terms from the Dolakhā dialect.

Table 2. Sibling kinship terms from the Dolakhā dialect of Thangmi

\begin{tabular}{lll}
\hline elder brother & $(\mathrm{eB})$ & bubu \\
elder sister & $(\mathrm{eZ})$ & tete \\
younger brother & $(\mathrm{yB})$ & hu \\
younger sister & $(\mathrm{yZ})$ & humi \\
\hline
\end{tabular}


Apart from one notable exception, sibling kinship terms are common to both dialects. In the Sindhupālcok dialect of Thangmi, the 'sex principle' is not strictly upheld: somewhat akin to Limbu (Davids and van Driem 1985: 122-123), both younger brother and younger sister are referred to by the same gender-indifferent term $h u$ 'younger sibling'. Aware of the confusion this can generate, speakers of the Sindhupālcok dialect may qualify the term $h u$ 'sibling' by prefacing it with either calaca 'male, man' or camaica 'female, woman', as in Table 3 below.

Table 3. Younger sibling kinship terms from the Sindhupālcok dialect

\begin{tabular}{lll}
\hline $\begin{array}{l}\text { younger brother } \\
\text { younger sister }\end{array}$ & $(\mathrm{yB})$ & $\begin{array}{l}\text { (calaca) } h u \\
\text { (camaica) } h u\end{array}$ \\
\hline
\end{tabular}

Age in generation also functions distinctively in kinship terms referring to members of the speaker's parents' generation. Thangmi kinship nomenclature distinguishes between uncles and aunts by blood and uncles and aunts by marriage, somewhat like Gurung (Pignède 1966), but unlike Limbu (Davids and van Driem 1985: 124). In the Dolakhā dialect, the age distinction is upheld for father's brothers only and not for father's sisters, as illustrated in Table 4.

Table 4. Father's siblings kinship terms from the Dolakhā dialect

\begin{tabular}{lll}
\hline father's elder brother & $(\mathrm{FeB})$ & jekhapa \\
father's younger brother & $(\mathrm{FyB})$ & ucyapa \\
father's sister (elder or younger) & $(\mathrm{FZ})$ & nini \\
\hline
\end{tabular}

In the Sindhupālcok dialect, the age distinction is upheld across all of father's siblings, as illustrated in Table 5.

Table 5. Father's siblings kinship terms from the Sindhupālcok dialect

\begin{tabular}{lll}
\hline father's elder brother & $(\mathrm{FeB})$ & jhya?apa \\
father's younger brother & $(\mathrm{FyZ})$ & pacyu \\
father's elder sister & $(\mathrm{FeZ})$ & jhya?ama \\
father's younger sister & $(\mathrm{FyZ})$ & nini \\
\hline
\end{tabular}


In Sindhupālcok, Thangmi speakers do not differentiate for the gender of a younger sibling, but do differentiate on the basis of age for a father's sister. On the other hand, speakers of the Dolakhā variety of Thangmi distinguish the gender of a younger sibling, but do not differentiate between father's elder sister and father's younger sister.

In the Sindhupālcok dialect, age in generation relative to the speaker's father is differentiated. In the Dolakhā dialect, parallel uncles, of the same gender as the parent, are distinct on the father's side, while cross aunts, of different gender to the parent, are not. This is reminiscent of Limbu kinship terminology in which there is only one term for 'father's sister' (FZ), nya?, and one for 'mother's brother' (MB), nwa?, indeterminate of age (Davids and van Driem 1985: 123).

The age in generation principle also functions distinctively in kinship terms for mother's siblings in both dialects. In both Dolakhā and Sindhupālcok, the Thangmi language upholds the age distinction for all four siblings of ego's mother, as shown in Tables 6 and 7.

Table 6. Mother's siblings kinship terms from the Dolakhā dialect

\begin{tabular}{lll}
\hline $\begin{array}{l}\text { mother's elder brother } \\
\text { mother's younger brother }\end{array}$ & $(\mathrm{MeB})$ & $\begin{array}{l}\text { palam } \\
\text { malam }\end{array}$ \\
mother's elder sister & $(\mathrm{MyZ})$ & jekhama \\
mother's younger sister & $(\mathrm{MeZ})$ & macyu \\
\hline
\end{tabular}

Table 7. Mother's siblings kinship terms from the Sindhupālcok dialect

\begin{tabular}{lll}
\hline $\begin{array}{l}\text { mother's elder brother } \\
\text { mother's younger brother }\end{array}$ & $(\mathrm{MeB})$ & $\begin{array}{l}\text { palam } \\
\text { mou }\end{array}$ \\
mother's elder sister & $(\mathrm{MyZ})$ & \\
mother's younger sister & $(\mathrm{MeZ})$ & jhyalama \\
\end{tabular}

In the Dolakhā dialect, the age in generation principle also applies to aunts and uncles by marriage on the father's side. Aunts by marriage on the father's side (FBW) are differentiated for age, while uncles by marriage on the father's side (FZH) are not, following the pattern outlined above. Table 8 illustrates the kinship terms for the spouses of father's siblings in the Dolakhā dialect of Thangmi. 
Table 8. Kinship terms for the spouses of father's siblings from the Dolakhā dialect

\begin{tabular}{|c|c|c|}
\hline $\begin{array}{l}\text { father's elder brother's wife } \\
\text { father's younger brother's wife }\end{array}$ & $\begin{array}{l}(\mathrm{FeBW}) \\
(\mathrm{FyBW})\end{array}$ & $\begin{array}{l}\text { jekhama } \\
\text { ucyama }\end{array}$ \\
\hline father's sister's husband (elder or younger) & $(\mathrm{FZH})$ & mama \\
\hline
\end{tabular}

It is worth noting that the kinship term for father's sister's husband (FZH) in the Dolakhā dialect, mama, is homophonous with the Nepali kinship term for mother's younger brother (MyB), māma $\bar{a}$. I believe these terms to be etymologically unrelated.

In the Sindhupālcok dialect, the age distinction is upheld across all of father's siblings' spouses, as illustrated in Table 9.

Table 9. Kinship terms for the spouses of father's siblings from the Sindhupālcok dialect

\begin{tabular}{lll}
\hline $\begin{array}{l}\text { father's elder brother's wife } \\
\text { father's younger brother's wife }\end{array}$ & (FeBW) & jhya?ama \\
macyu & (FyBW) & jhya?apa \\
father's elder sister's husband & (FeZH) & mou \\
father's younger sister's husband & (FyZH) & mou \\
\hline
\end{tabular}

In the Dolakhā dialect, the age in generation principle similarly applies to aunts and uncles by marriage on the mother's side. Uncles by marriage on the mother's side (MZH) are differentiated for age, while aunts by marriage on the mother's side (MBW) are not, following the pattern outlined above. Table 10 illustrates the kinship terms from the Dolakhā dialect used for spouses of the mother's siblings.

Table 10. Kinship terms for spouses of the mother's siblings from the Dolakhā dialect

\begin{tabular}{lll}
\hline mother's elder sister's husband & $(\mathrm{MeZH})$ & jekhapa \\
mother's younger sister's husband & $(\mathrm{MyZH})$ & pacyu \\
mother's brother's wife (elder or younger) & $(\mathrm{MBW})$ & nini \\
\hline
\end{tabular}

In the Sindhupālcok dialect, the age distinction is upheld across all of the mother's siblings' spouses, as shown in Table 11. 
Table 11. Kinship terms for spouses of the mother's siblings from the Sindhupālcok dialect

\begin{tabular}{lll}
\hline $\begin{array}{l}\text { mother's elder sister's husband } \\
\text { mother's younger sister's husband }\end{array}$ & (MeZH) & jhya?apa \\
& $(\mathrm{MyZH})$ & phus?apa \\
mother's elder brother's wife & $(\mathrm{MeBW})$ & malam \\
mother's younger brother's wife & $(\mathrm{MyBW})$ & nini \\
\hline
\end{tabular}

There are some crucial differences between the Dolakhā and Sindhupālcok dialects regarding uncles and aunts by blood and by marriage, as illustrated in the examples above. In the Dolakhà dialect, cross aunts (father's sisters) and their spouses are not differentiated for age, while in the Sindhupālcok dialect they are. Other Tibeto-Burman languages configure these kinship relationships differently. In Limbu, for example, kinship nomenclature makes no distinction between uncles and aunts by blood versus uncles and aunts by marriage (Davids and van Driem 1985: 123-124), while in Gurung, the terms for aunt and uncle by blood are distinct from those for aunt and uncle by marriage, as in the Sindhupālcok dialect of Thangmi. With the exceptions noted above, then, uncles and aunts by marriage are terminologically differentiated in Thangmi on the basis of age within generation of spouse relative to ego's parent.

In both dialects of Thangmi, both cross-cousins and parallel cousins are classified as siblings, and a marriage taboo exists between ego and any cousin, cross or parallel. Unlike other Tibeto-Burman groups in Nepal, such as the Thakali, Tamang or Gurung, the Thangmi do not practice preferential cross-cousin marriage (i.e., ego with MBD or FZS). In the Thangmi language, the age of ego determines whether a male cousin is called 'elder brother' or 'younger brother', not the birth order of their parents. In other words, the son of ego's palam $(\mathrm{MeB})$ is termed $h u(\mathrm{yB})$ when younger than ego, even though this individual's father is older than ego's mother. As with younger siblings, the Sindhupālcok dialect does not differentiate between gender for cousins: Both younger male cousin and younger female cousin are termed $h u$. This is illustrated in Table 12.

Table 12. Kinship terms for cousins in both dialects

\begin{tabular}{ll}
\hline elder male cousin & bubu \\
elder female cousin & tete \\
younger male cousin & hu (Dolakhā) \\
younger female cousin & humi (Dolakhā) \\
younger cousin (male or female) & hu (Sindhupālcok) \\
\hline
\end{tabular}


While the kinship terms for cousins are not differentiated by the gender of their parents, the terms for nephews and nieces are. In Dolakhā as in Sindhupālcok, the children of ego's brothers are classificatory children and responsibilities to them are akin to responsibilities for one's own children. On the other hand, sister's children are regarded as nephews and nieces, and the main social responsibility for them lies with the siblings of the sister's husband (ZHB and ZHZ). The kinship terms for ego's children and the children of ego's siblings are the same in both dialects of Thangmi, and are given in Table 13 below.

Table 13. Kinship terms for ego's children and children of ego's siblings in both dialects

\begin{tabular}{lll}
\hline son, brother's son & (S), (BS) & ca \\
daughter, brother's daughter & (D), (BD) & camai \\
sister's son & (ZS) & baine \\
sister's daughter & (ZD) & bini \\
\hline
\end{tabular}

In the Sindhupālcok dialect, neither the gender of a grandchild nor the gender of his or her parent is expressed in the kinship term. Daughters' sons and daughters, as well as sons' sons and daughters are all referred to as cacha (SS, SD, DS, DD). The same does not hold for the Dolakhā dialect, in which the gender of a grandchild is made explicit, but the gender of his or her parent remains immaterial. This is demonstrated in Table 14.

Table 14. Kinship terms for grandchildren in the Dolakhā dialect

\begin{tabular}{ll}
\hline son's son, daughter's son & (SS), (DS) \\
son's daughter, daughter's daughter & (SD), (DD) \\
\end{tabular}

A handful of speakers of the Sindhupālcok dialect, particularly from the village of Cokațī, insist that Thangmi kinship terms for great-grandchildren, great-great-grandchildren and even great-great-great-grandchildren exist and are in common use. While older speakers from this village use these terms, they have not been corroborated by other native speakers beyond this village. It is interesting to note that while grandchildren are not differentiated for gender, as both grandson and granddaughter are termed cacha, gender differentiation does exist for the following generations, as shown in Table 15 below. It is likely that the element /-ni/, present in the kinship terms for greatgranddaughter and great-great-granddaughter, is of Nepali origin. 
Table 15. Kinship terms for four generations of grandchildren in the Sindhupālcok dialect (Cokațī village)

\begin{tabular}{ll}
\hline grandson & cacha \\
granddaughter & cacha \\
great-grandson & cayã \\
great-granddaughter & cayãni \\
great-great-grandson & cuyũ \\
great-great-granddaughter & cuyũni \\
great-great-great-grandson & $\tilde{\text { uyu }}$ \\
great-great-great-granddaughter & $\tilde{u} y u n i$ \\
\hline
\end{tabular}

Similar to Thangmi kinship terms for siblings, the terms for brothers-inlaw and sisters-in-law distinguish both for sex of referent and for relative age of sibling. Aside from a regular phonological variation, these terms are the same in both dialects, as shown in Table 16.

Table 16. Kinship terms for siblings-in-law in both dialects

\begin{tabular}{|c|c|c|}
\hline $\begin{array}{l}\text { elder brother's wife } \\
\text { elder sister's husband }\end{array}$ & $\begin{array}{l}(\mathrm{eBW}) \\
(\mathrm{eZH})\end{array}$ & $\begin{array}{l}\text { pairi poiri } \\
\text { jarphu }\end{array}$ \\
\hline $\begin{array}{l}\text { younger brother's wife } \\
\text { younger sister's husband } \\
\text { younger sister's husband }\end{array}$ & $\begin{array}{l}(\mathrm{yBW}) \\
(\mathrm{yZH}) \\
(\mathrm{yZH})\end{array}$ & $\begin{array}{l}\text { hu wari } \\
\text { (humi) d̦amari (Dolakhā) } \\
\text { jyamai (Sindhupālcok) }\end{array}$ \\
\hline
\end{tabular}

The Thangmi term wari is rarely used without a preceding kinship term to qualify it. On its own, with no qualification, wari occupies a lexical domain identical to Nepali buhāri. Both Thangmi wari and Nepali buhāri have a range of meanings which fall within the category of 'wife of male kin younger than ego'. The lexical item wari may be a loan from Nepali buhāri, since the intervocalic [h] in buhāri elides in allegro Nepali speech, and the initial $[\mathrm{b}]$ in Nepali is often realised as [w] in Thangmi.

In combination with a prefixed qualifier Thangmi wari covers a range of meanings including 'younger brother's wife' (yBW), 'brother's son's wife' (BSW), 'son's wife' (SW), 'son's son's wife' (SSW), 'daughter's son's wife' (DSW) and 'sister's son's wife' (ZSW), as illustrated in Table 17. 
Table 17. The range of meanings for Thangmi wari in both dialects

\begin{tabular}{lll}
\hline younger brother's wife & $(\mathrm{yBW})$ & hu wari \\
brother's son's wife & $(\mathrm{BSW})$ & ca wari \\
son's wife & (SW) & ca wari \\
son's son's wife & (SSW) & cacha wari \\
daughter's son's wife & (DSW) & cacha wari \\
sister's son's wife & (ZSW) & $\begin{array}{l}\text { baine wari (Dolakhā) } \\
\text { bini wari (Sindhupālcok) }\end{array}$ \\
\hline
\end{tabular}

A semantic field similar to that of wari is occupied by the Thangmi kinship term ḍamari (Dolakhā) or jyamari (Sindhupālcok). The term ḍamari jyamari is also rarely used without a preceding qualifier. Without qualification, damari jyamari occupies a domain identical to Nepali javãu, which has a range of meanings encompassed within 'husband of female kin younger than ego'. It is possible that Thangmi damari $\sim$ jyamari is etymologically related to Nepali javāĩ. In combination with a prefixed qualifier, Thangmi damari $\sim$ jyamari has a range of meanings which include 'younger sister's husband' (yZH), 'brother's daughter's husband' (BDH), 'daughter's husband' (DH), 'son's daughter's husband' (SDH), 'daughter's daughter's husband' (DDH) and 'sister's daughter's husband' (ZDH), as shown in Tables 18 and 19 below.

Table 18. The range of meanings for Thangmi damari in the Dolakhā dialect

\begin{tabular}{lll}
\hline younger sister's husband & $(\mathrm{yZH})$ & humi damari \\
brother's daughter's husband & $(\mathrm{BDH})$ & camai damari \\
daughter's husband & $(\mathrm{DH})$ & camai damari \\
son's daughter's husband & $(\mathrm{SDH})$ & cachi damari \\
daughter's daughter's husband & $(\mathrm{DDH})$ & cachi damari \\
sister's daughter's husband & $(\mathrm{DDH})$ & bini damari \\
\hline
\end{tabular}

Table 19. The range of meanings for Thangmi jyamari in the Sindhupālcok dialect

\begin{tabular}{lll}
\hline younger sister's husband & $(\mathrm{yZH})$ & jyamari \\
brother's daughter's husband & $(\mathrm{BDH})$ & camai jyamari \\
daughter's husband & $(\mathrm{DH})$ & camai jyamari \\
son's daughter's husband & $(\mathrm{SDH})$ & cacha jyamari \\
daughter's daughter's husband & $(\mathrm{DDH})$ & cacha jyamari \\
sister's daughter's husband & $(\mathrm{DDH})$ & bini jyamari \\
\hline
\end{tabular}


Related to the term damari is the kinship term damarni, with a general meaning of 'sister of husband of female kin younger than ego' and specifically used for younger sister's husband's sister (yZHZ) and daughter's husband's sister (DHZ), as shown in Table 20. This term is used only by speakers of the Dolakhā dialect.

Table 20. The two meanings for Thangmi damarni in the Dolakhā dialect

\begin{tabular}{lll}
\hline $\begin{array}{l}\text { younger sister's husband's sister } \\
\text { daughter's husband's sister }\end{array}$ & $\begin{array}{l}\text { (yZHZ) } \\
\text { (DHZ) }\end{array}$ & $\begin{array}{l}\text { damarni } \\
\text { damarni }\end{array}$ \\
\hline
\end{tabular}

\section{Sex of speaker}

The kinship systems of certain Tibeto-Burman languages distinguish for sex of speaker. In certain dialects of Tibetan, for example, kinship terms distinguish between elder siblings on the basis of the speaker's gender. A sex distinction is also made in Limbu, and Benedict maintains that it "must be regarded as archaic for the group as a whole" (1941: 319, cited in Davids and van Driem 1985: 125). While sex of speaker is not generally distinctive in Thangmi, a select few kinship terms, such as those for siblings-in-law and uncles- and aunts-in-law, do reflect the Tibeto-Burman sex of speaker criterion.

A number of structural features of the Thangmi kinship terms which distinguish for sex of speaker should be highlighted. In the Dolakhā dialect of Thangmi, all such terms relate to affinal rather than blood kin, people related by marriage rather than descent, and are secondary extensions of the primary meaning of a specific kinship term. For example, aji, which means first and foremost 'mother-in-law' has the secondary meaning 'wife's elder sister'. Likewise, tete has a primary meaning of 'elder sister' and a secondary meaning of 'husband's elder sister'. Kinship terms from the Dolakhā dialect which are distinctive for sex of speaker are shown in Table 21 below, and those from the Sindhupālcok dialect are presented in Table 22. 
Table 21. Kinship terms distinctive for sex of speaker in the Dolakhā dialect

\begin{tabular}{lll}
\hline $\begin{array}{l}\text { wife's elder sister } \\
\text { husband's elder sister }\end{array}$ & $\begin{array}{l}\text { (WeZ) } \\
(\mathrm{HeZ})\end{array}$ & $\begin{array}{l}\text { aji } \\
\text { tete }\end{array}$ \\
$\begin{array}{l}\text { wife's mother's younger brother } \\
\text { husband's mother's younger brother }\end{array}$ & $\begin{array}{l}\text { (WMyB) } \\
\text { (HMyB) }\end{array}$ & $\begin{array}{l}\text { malam chuku } \\
\text { mou chuku }\end{array}$ \\
$\begin{array}{l}\text { wife's mother's younger brother's wife } \\
\text { husband's mother's younger brother's wife }\end{array}$ & $\begin{array}{l}\text { (WMyBW) } \\
\text { (HMyBW) }\end{array}$ & $\begin{array}{l}\text { malam aji } \\
\text { nini }\end{array}$ \\
$\begin{array}{l}\text { wife's mother's younger sister's husband } \\
\text { husband's mother's younger sister's husband }\end{array}$ & $\begin{array}{l}\text { (WMyZH) } \\
\text { (HMyZH) }\end{array}$ & $\begin{array}{l}\text { pacyu chuku } \\
\text { ocyana chuku }\end{array}$ \\
\hline
\end{tabular}

Table 22. Kinship terms distinctive for sex of speaker in the Sindhupālcok dialect

\begin{tabular}{|c|c|c|}
\hline $\begin{array}{l}\text { wife's elder sister } \\
\text { husband's elder sister }\end{array}$ & $\begin{array}{l}(\mathrm{WeZ}) \\
(\mathrm{HeZ})\end{array}$ & $\begin{array}{l}\text { jhya?ama } \\
\text { malam ca }\end{array}$ \\
\hline wife's elder sister's husband & $(\mathrm{WeZH})$ & bubu \\
\hline husband's elder sister's husband & $(\mathrm{HeZH})$ & jhya?apa \\
\hline wife's elder sister's son & (WeZS) & $c a$ \\
\hline husband's elder sister's son & $(\mathrm{HeZS})$ & baine \\
\hline wife's elder sister's daughter & (WeZD) & camai \\
\hline husband's elder sister's daughter & (HeZD) & bini \\
\hline wife's elder sister's son's wife & (WeZSW) & ca wari \\
\hline husband's elder sister's son's wife & $(\mathrm{HeZSW})$ & bini wari \\
\hline wife's elder sister's daughter's husband & (WeZDH) & camai jyamari \\
\hline husband's elder sister's daughter's husband & (HeZDH) & bini jyamari \\
\hline wife's mother's younger brother & (WMyB) & mou chuku \\
\hline husband's mother's younger brother & (HMyB) & malam chuku \\
\hline wife's mother's younger brother's wife & (WMyBW) & nini aji \\
\hline husband's mother's younger brother's wife & (HMyBW) & malam aji \\
\hline wife's mother's younger sister's husband & (WMyZH) & ocyana chuku \\
\hline husband's mother's younger sister's husband & (HMyZH) & pacyu chuku \\
\hline
\end{tabular}


It is apparent that there is a greater differentiation for sex of speaker in the Sindhupālcok dialect than in the Dolakhā dialect. In the Sindhupālcok dialect, the sex of speaker criterion is applied to offspring-in-law, specifically the children of ego's spouse's elder sister, while in the Dolakhā dialect the differentiation does not extend so far. Second, aside from the extension of the system to include children of one's spouse's elder sister, the kin for whom sex of speaker is differentiated are the same in both dialects: spouse's elder sister, spouse's mother's younger brother and his wife, and spouse's mother's younger sister's husband. Why these terms should be differentiated for sex of speaker when others are not is unclear, since none of the differentiated kin are socially or ritually more important to ego than other similarly positioned kin in Thangmi society.

Finally, it is intriguing to note that the sex-differentiated terms for mother's younger siblings are reversed in the two dialects. This reversal may be attributed to linguistic attrition and language decay, processes by which rarely used and socially less important kinship terms may be the first to be confused and eventually lost. Moreover, while Benedict posited that the archaic Tibeto-Burman sex of speaker distinction applied to elder sibling kinship terminology, the above examples show that Thangmi also differentiates for spouse's elder sister and mother's younger siblings.

In the Dolakhā dialect, a further terminological distinction is made between siblings-in-law related to ego via a spouse (married kin) versus relationships through ego's siblings (blood kin). For example, the terms for sister-in-law differ depending on whether the referent is related to the speaker through the speaker's sibling or through the speaker's spouse: 'elder brother's wife' (eBW) pairi versus 'wife's elder sister' (WeZ) aji. The Dolakhā dialect makes this distinction for all siblings-in-law.

Referring to siblings-in-law and their spouses with one of the terms for ego's own siblings, bubu (eB), tete (eZ), hu (yB) and humi (yZ), may be explained in one of two ways. On the one hand, the relationship between an ego and his or her spouse's siblings is often close, which may be reflected in the extension of kinship terminology from ego's own siblings to those of ego's spouse. Many Thangmi men and women view their spouse's siblings as de facto brothers and sisters. ${ }^{7}$ On the other hand, the use of sibling kinship terms for siblings-in-law may not carry a particular cultural meaning. After all, familial kinship terms, such as the terms denoting grandparents, parents, siblings and children, are the most commonly used forms of ad- 
dress for non-kin in both professional and social encounters. Kinship terms for uncles and aunts are less frequently used to address non-kin, since their use invokes a notional kinship bond which reckons descent through one parent over the other. ${ }^{8}$ In both dialects of Thangmi, the kinship terms $b u b u$ 'elder brother' and tete 'elder sister' are widely used as respectful terms of address for male and female strangers around the age of the speaker.'

A terminological distinction absent in Thangmi, but present in Nepali and in many of the Tibeto-Burman languages of Nepal, is one which indicates an individual's age within generation by order of birth. In certain Tibeto-Burman languages, such as Limbu, kinship terms for age within generation are derived from ordinal numbers, while in Nepali, specifically gendered kinship forms exist for 'first-born male', 'first-born female', 'second-born male', 'second-born female', etc. ${ }^{10}$ The only comparable Thangmi form is jekha 'large, big', which is occasionally used as a term of address to attract the attention of the eldest male child. Its use conveys a sense of anger or dissatisfaction on the part of the speaker, which may explain its limited use.

The examples and tables provided above illustrate a number of the most commonly occurring kinship terms and structural issues present in both dialects of Thangmi. The kinship terms and the relationships they encode are given in full schematic form at the end of this article.

\section{The morphology of Thangmi kinship terms}

A number of Thangmi kinship terms yield readily to language-internal morphological analysis. A point worth noting at the outset is the frequency of reduplicative, near reduplicative or mirrored forms, such as $b u b u$ 'elder brother', cacha 'grandson', mama 'father's sister's husband', nini 'father's sister' and tete 'elder sister'. This manner of doubling is a common and well-attested feature of kinship terminologies in many of the world's languages, including the Tibeto-Burman languages spoken in Nepal.

The kinship term cacha 'grandson' is a reduplicative form of ca 'son' combined with an aspirated second element cha. Younger and imperfect Thangmi speakers frequently use an unaspirated second element, thus *caca, a form universally rejected by fluent Thangmi speakers. The morphological composition of cacha is transparent: 'son of son'. 
Both dialects of Thangmi have a number of kinship terms in which female gender is indicated by a final /-i/ or /-ni/, such as cacha 'grandson' versus cachi 'granddaughter', țhone 'old man' versus țhoni 'old woman', damari 'son's wife' versus damarni 'daughter's husband's sister', and jarphu 'elder sister's husband' versus jarphuni 'elder sister's husband's sister'. This sex differentiation may be a remnant of an old system of grammatical gender or an indication of more recent contact with Indic languages such as Nepali, in which the $<-\mathrm{i} \sim-n \mathrm{i}>$ ending is common in female kinship terms such as chorā 'son' versus chori 'daughter', and is also used to indicate biological sex in non-human animates, such as kukur 'hound' versus kukurn̄̄ 'bitch'.

The suggestion that this final /-i/ may be loaned from Nepali gains credibility in light of the gendered nature of other Thangmi kinship terms. In Thangmi kinship terminology, as in the lexicon in general, biological gender can be emphasised or disambiguated with one of two gendered prefixes, $<$ ma- $\sim$ mama-> (FEM) or $<$ pa- $\sim$ papa-> (MALE). In the non-kinship lexicon, examples of this productive morphological process are mama-sya (FEM-bovine) 'cow', papa-kucu (MALE-dog) 'hound' and mama-yante (FEM-quern) 'lower part of a millstone or quern'. In the kinship lexicon, these same gendered prefixes are found as fused elements of the noun, such as macyu (MyZ) 'mother's younger sister' versus pacyu (MyZH) 'mother's younger sister's husband' or malam (MyB) 'mother's younger brother' versus palam (MeB) 'mother's elder brother'. These terms function as gendered pairs, offering both a female and a male side of a respective kinship relationship. It is interesting to note, however, that the structural opposition between macyu : pacyu is semantically distinct from malam : palam. In the Dolakhā dialect, the first pair refers to an aunt and her husband, while the second pair refers to a younger uncle and an elder one. My working hypothesis is that the <ma- $\sim$ mama- $>$ and $<$ pa- $\sim$ papa- $>$ prefixes are more likely to be indigenous to Thangmi, given their presence throughout the whole lexicon, while the final element /-i/ found in some female kinship terms is a later loan from Sanskrit or Nepali.

A further interesting morphological feature relates to the compounding of kinship forms, such as jekhama in Dolakhā and jhya?ama in Sindhupālcok meaning 'mother's elder sister' (MeZ), and both derived from jekha jhya 'big, large, senior' and ama 'mother'. In the Dolakhā form, the /a/ elides and the form is fused, while in the Sindhupālcok dialect, the bound- 
ary of the two elements is glottalized producing /-a?a-/. The same morphophonological patterns are at play in jekhapa (Dolakhā) and jhyalapa (Sindhupālcok) 'father's elder brother' (FeB) respectively.

Other compounded kinship terms make use of the elements ocyana or $u c y a$, both meaning 'small', as in the non-fused kinship term ocyana chuku, literally 'small father-in-law', meaning 'husband's mother's younger sister's husband' and the fused ucyapa, literally 'small father', meaning 'father's younger brother'. These forms may be calques from Nepali, as in Thangmi jekhapa, literally 'big father', 'father's elder brother' (FeB) from Nepali thūlo $b \bar{a}$ 'father's elder brother' (FeB), with the same literal meaning. Another qualifying prefix used in compounded kinship terms is thone (Dolakhā) or chyode (Sindhupālcok) 'old male', and the associated female form, thoṇi (Dolakhā) or chyoḍi (Sindhupālcok) 'old female'. Used as prefixal qualifiers, these lexical items add a generation to the kinship term which they prefix, such as chuku 'father-in-law' versus thone chuku 'father-in-law's father', or aji 'mother-in-law' versus thoṇi aji 'mother-inlaw's mother'. Although infrequent, I have heard the kinship term thone apa, literally 'old male father', used to address a grandfather, a compound created by logical extension given the absence of an indigenous Thangmi kinship term for 'grandfather'.

\section{Thangmi kinship terms and their Tibeto-Burman cognates}

Here, I relate Thangmi kinship terms to reconstructed Tibeto-Burman etyma and offer a number of cognates from the extant Tibeto-Burman languages of Nepal.

The Thangmi terms ama 'mother', apa 'father' and $c a$ 'son' correspond to the Tibeto-Burman roots reconstructed by Benedict * $m a$ 'mother' (1972: 148), *pa 'father' (1972: 19) and *tsa *za 'child (offspring)' (1972: 27). The Thangmi kinship term $h u$ 'younger brother' (Dolakhā) or 'younger sibling' (Sindhupālcok), may well be cognate with Classical Tibetan $n u$ 'younger sibling', the latter also being present in compounds to give gender-specific younger sibling terms. Thangmi $\mathrm{ca}$ 'son' and camai 'daughter' are cognate with Thakali and Darjeeling Tamang ca 'son' and came 'daughter' (Vinding 1979: 208-215), and Gurung cxa 'son' (Glover, Glover, and Gurung 1977: 22) and camĩ or cami 'daughter' (Glover, Glover, and Gurung 1977: 17). Thangmi bubu 'elder brother' is cognate 
with Tibetan $p h u$ 'elder brother', corresponding to the Tibeto-Burman root *puw meaning 'grandfather', which has retained this meaning in some extant Tibeto-Burman languages. According to Benedict, however, *puw has undergone a "striking semantic transference" (1941: 319), and adopted the meaning 'elder brother' in certain Tibeto-Burman languages, such as Limbu phu 'elder brother' (van Driem 1987: 502) and Kulung bu 'elder brother' (Tolsma 1999: 197).

Thangmi nini 'father's sister, mother's brother's wife' corresponds to Tibeto-Burman *ni(y) 'aunt' (Benedict 1972: 69), and also to Newar nini 'the husband's sister, the father's sister' (Jørgensen 1936: 101), Limbu nya? 'ego's paternal aunt, wife of ego's maternal aunt' (van Driem 1987: 483), Dumi nini 'paternal aunt' (van Driem 1993: 402), Bumthang nene 'father's sister' (van Driem 1995: 54), Yamphu nini 'wife of mother's brother' (Rutgers 1998: 560) and Kulung $n i$ 'paternal aunt' (Tolsma 1999: 223).

Benedict posits the root $* t s$ ' $e$ 'great, old' underlying many honorific kinship terms in Tibetan, such as che-ba and chen-po 'great'. Thangmi chyoụe 'senior, big, large' (Sindhupālcok) and thoṇe (Dolakhā) may be cognate with the same Tibetan or Tibeto-Burman root. Benedict (1972: 27) posits a root *tsa for 'grandchild' as well as 'child' for the 'Tibetanized languages of Nepal', related to or ultimately derived from Tibeto-Burman 'tsa $\sim^{*} z a$ 'child (offspring)'. Thangmi cacha 'grandchild' would fit well within such an analysis.

A number of Thangmi kinship terms appear to be cognate with Classical Newar forms, and are not readily attested in other Tibeto-Burman languages spoken in Nepal. These Thangmi-Newar lexical correspondences include Thangmi cacha jyamari 'granddaughter's husband' and Classical Newar chaya jīri 'grand-daughter's husband' (Malla 2000: 131), Thangmi tete 'elder sister' and Classical Newar tatā 'an elder sister' (Jørgensen 1936: 75) or tatāju 'elder sister (hon.)' (Malla 2000: 170), and Thangmi pairi 'elder brother's wife' and Classical Newar pairabe 'an elder brother's wife' (Malla 2000: 296). ${ }^{11}$

\section{Conclusion}

In Thangmi, kinship terms are employed to address and refer to consanguineal and affinal relatives. Kinship terms generally replace an individual's given name, both as a term of address and for reference. Moreover, 
when kinship terms are used metaphorically as terms of address and reference for non-kin, a person's age and social position with respect to the speaker determines the choice of kinship term. For example, an elderly man may address a younger man as ca 'son' or cacha 'grandson', depending on how great he perceives the age difference to be. The metaphorical usage of kinship terms to apply to non-kin is widely observed among languages spoken in Nepal, including Nepali. Unlike Nepali, however, Thangmi has no system of ordinal terms to refer to the birth order of children within a generation.

In their study of Limbu kinship, Davids and van Driem conclude that "no inferences about the social structure amongst the Limbus can be made on the basis of the fieldwork conducted with its emphasis on linguistic aspects of kinship terminology" (1985: 141). They explicitly follow Kroeber's view that "terms of kinship reflect psychology, not sociology. They are determined primarily by language and can be used for sociological inferences only with extreme caution" (1909: 84, as cited in Davids and van Driem 1985: 140). While I agree that great care must be taken when attempting to construct social meaning from the lexicon of a language, I would suggest that a detailed analysis of kinship terminology supported by in-depth ethnographic research may provide a basis for forming a number of preliminary hypotheses about the characteristic features of Thangmi culture.

For example, I have noted the relative isolation of grandparents in Thangmi society and their absence from the daily social lives of their grandchildren, as well as the Thangmi preference for nuclear rather than joint family household composition. It comes as little surprise then, that the kinship terminology of Thangmi shows no indigenous terms for grandparents: ${ }^{12}$ their social absence is mirrored by a lexical absence. A further interesting socio-linguistic feature is the presence of female clan structures for women. Although practically defunct, the very existence of these clans indicates the presence of a gender distinction in Thangmi society, a feature which may be reflected in the linguistic differentiation for sex of speaker. In short, gendered clans and nuclear families are cultural characteristics of Thangmi life which have observable social and linguistic forms. 


\section{Appendix: Thangmi kinship charts}

Thangmi kinship terms for offspring in Sindhupālcok

child

grandchild
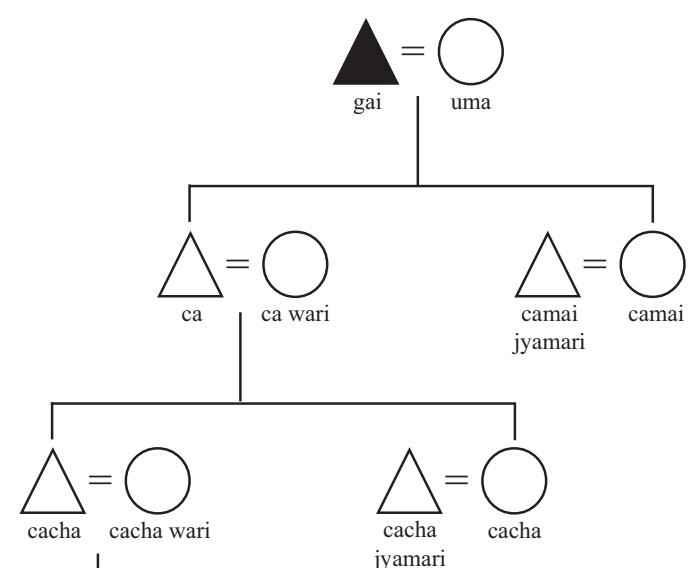

great-grandchild
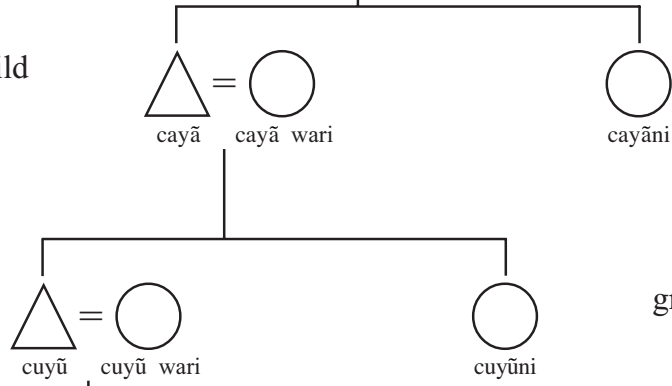

great-great-grandchild
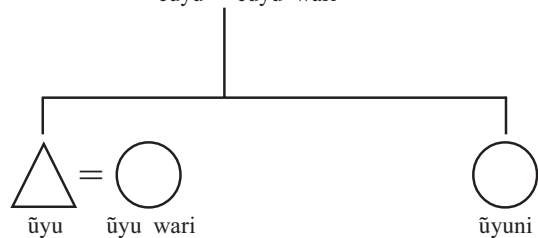

great-great-great-grandchild 


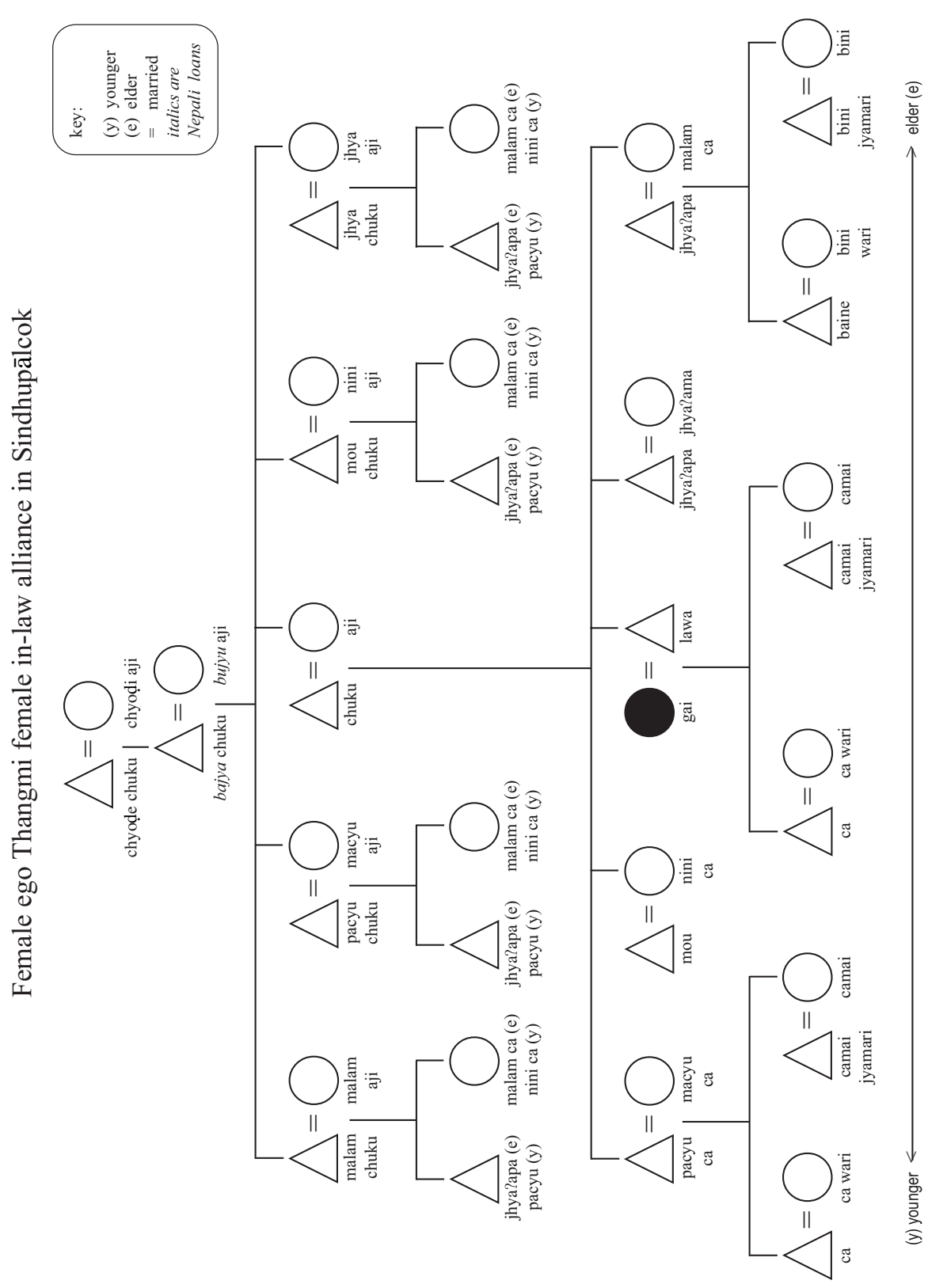




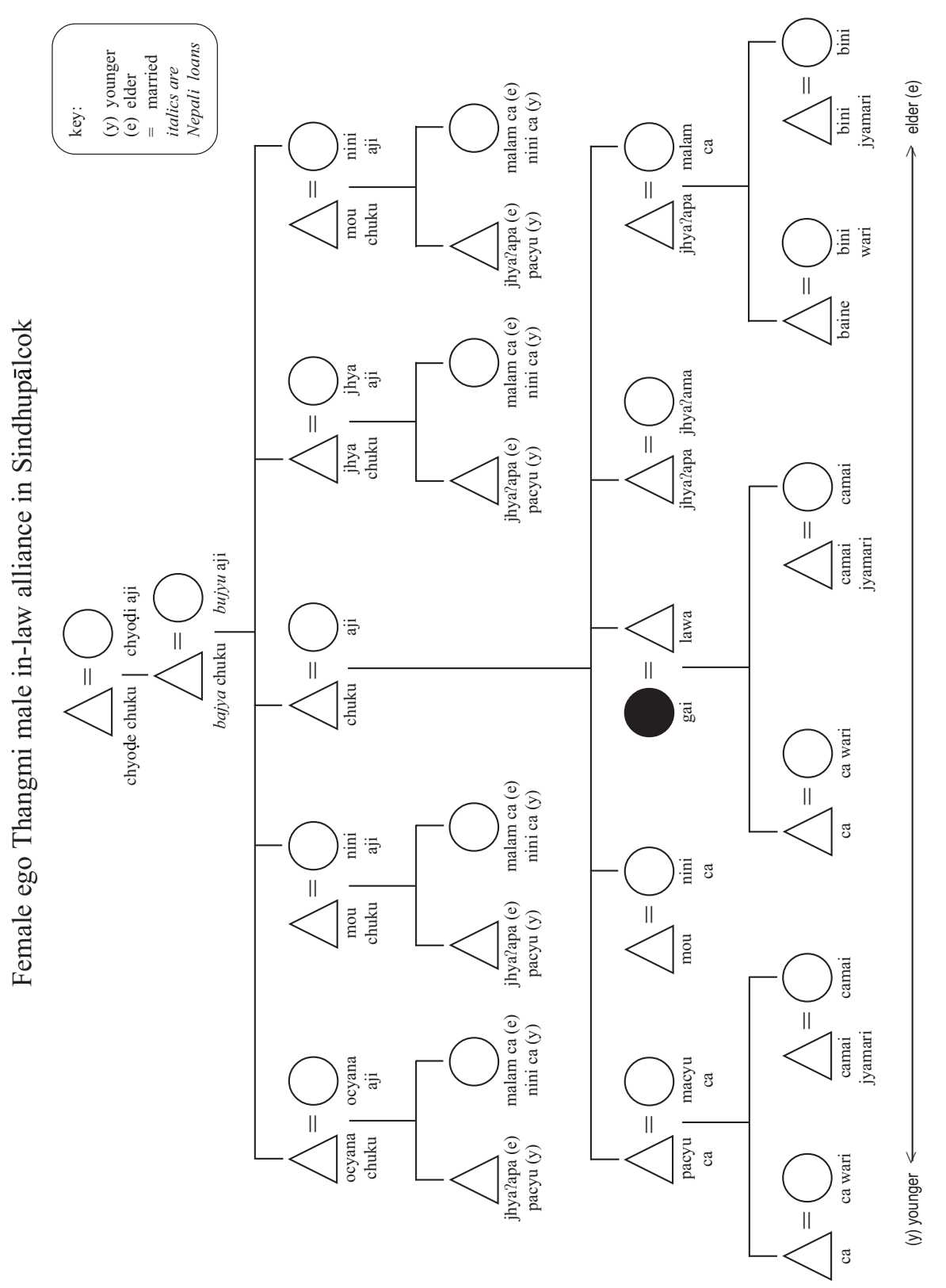




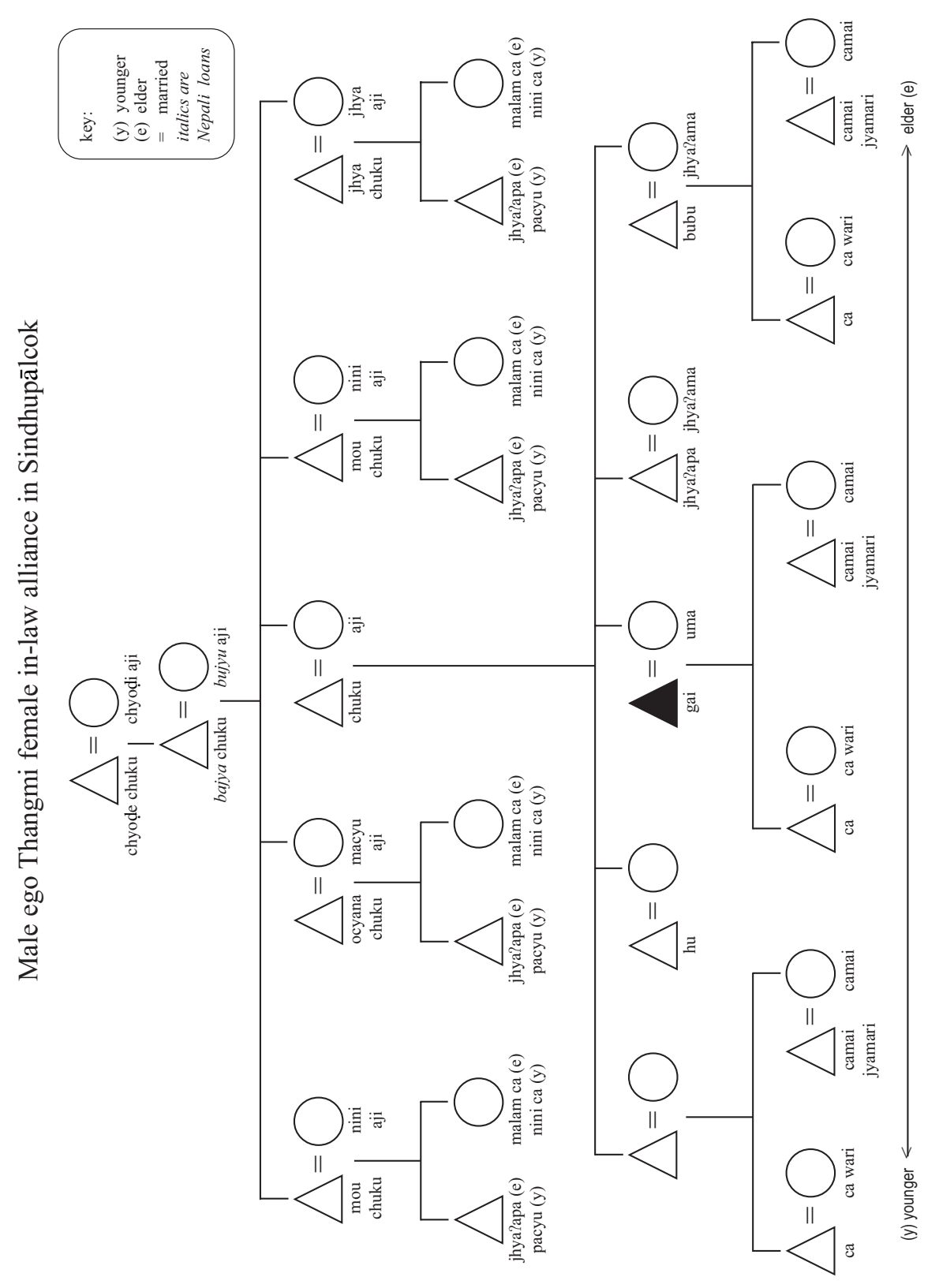




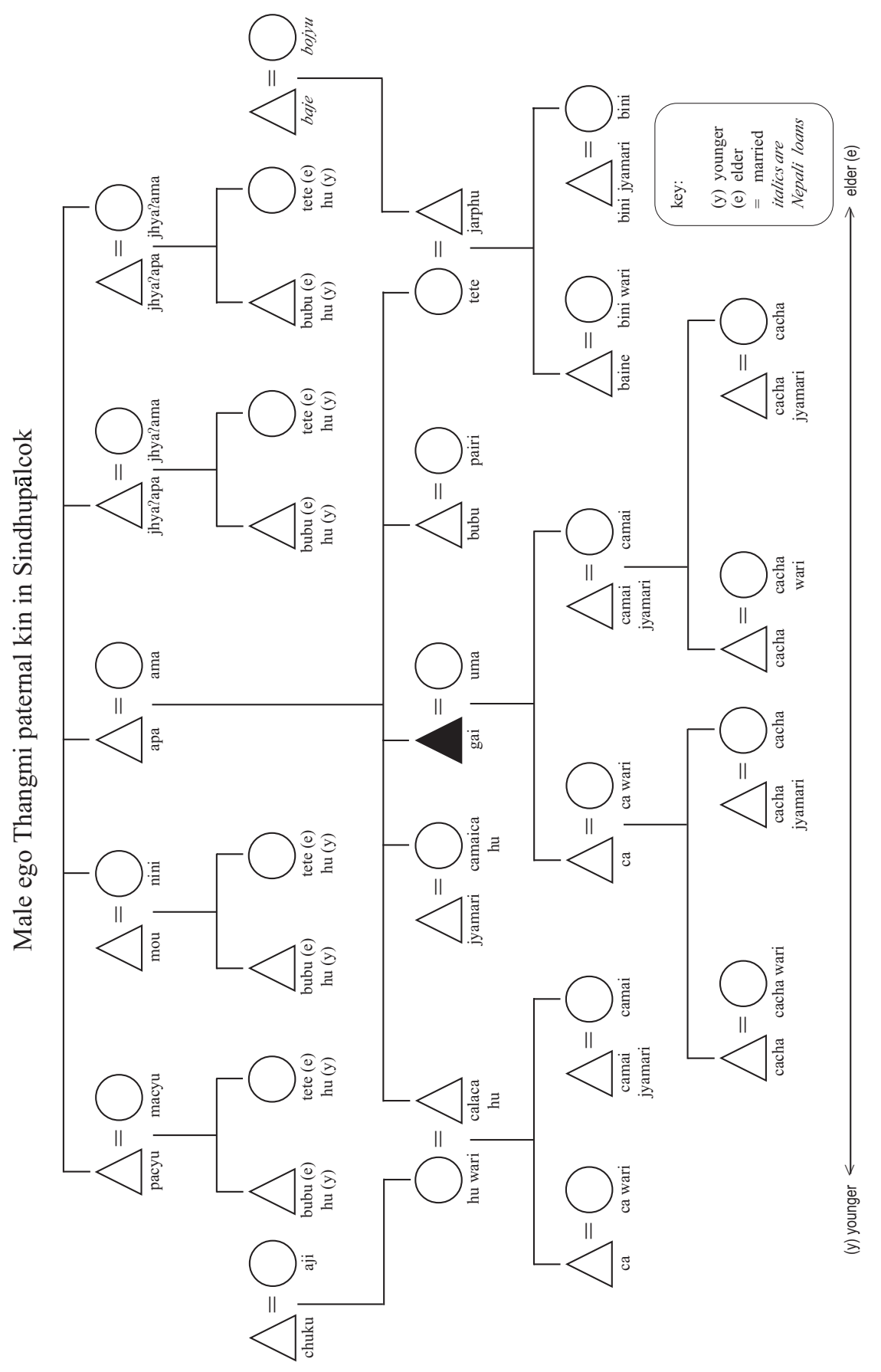




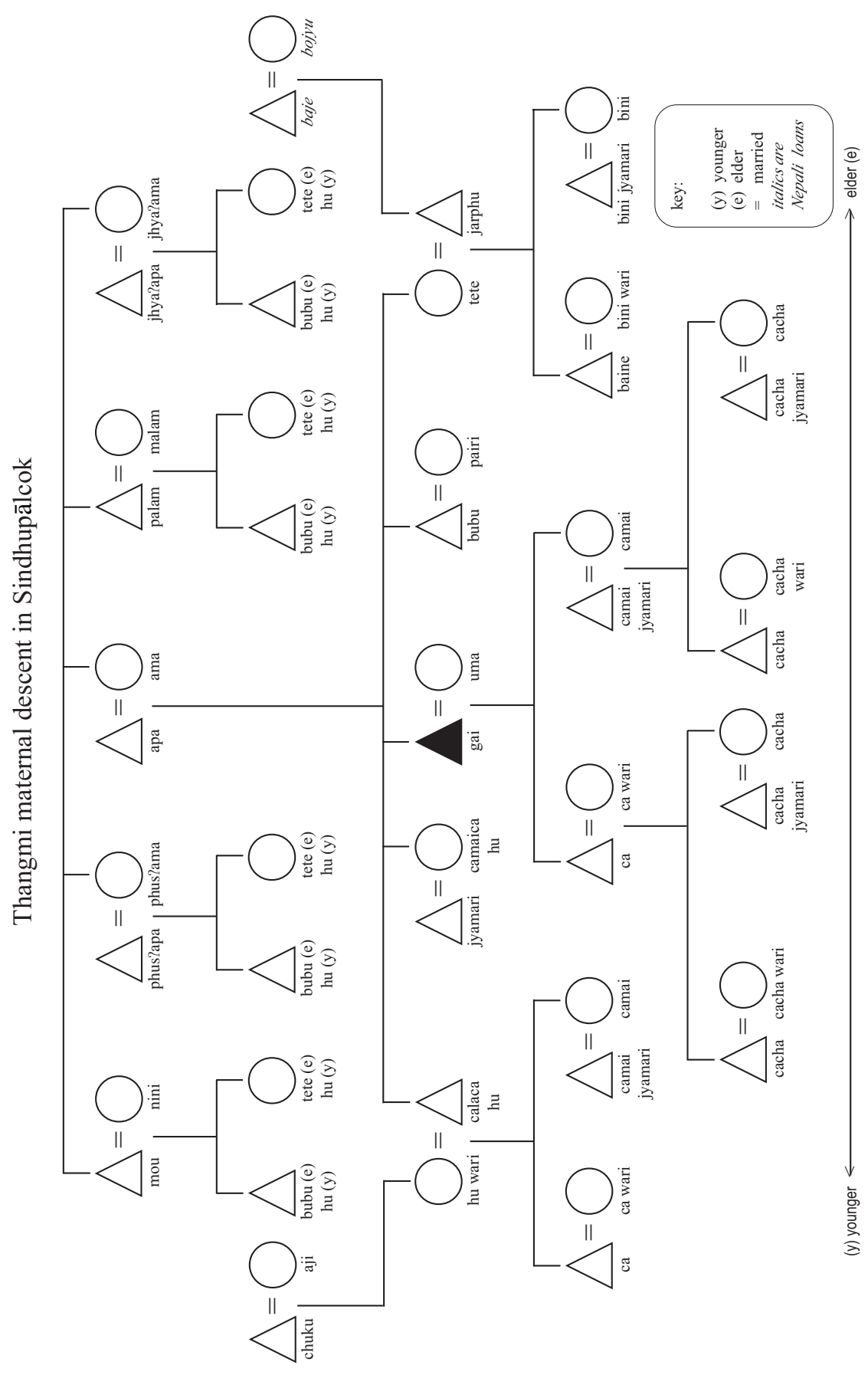




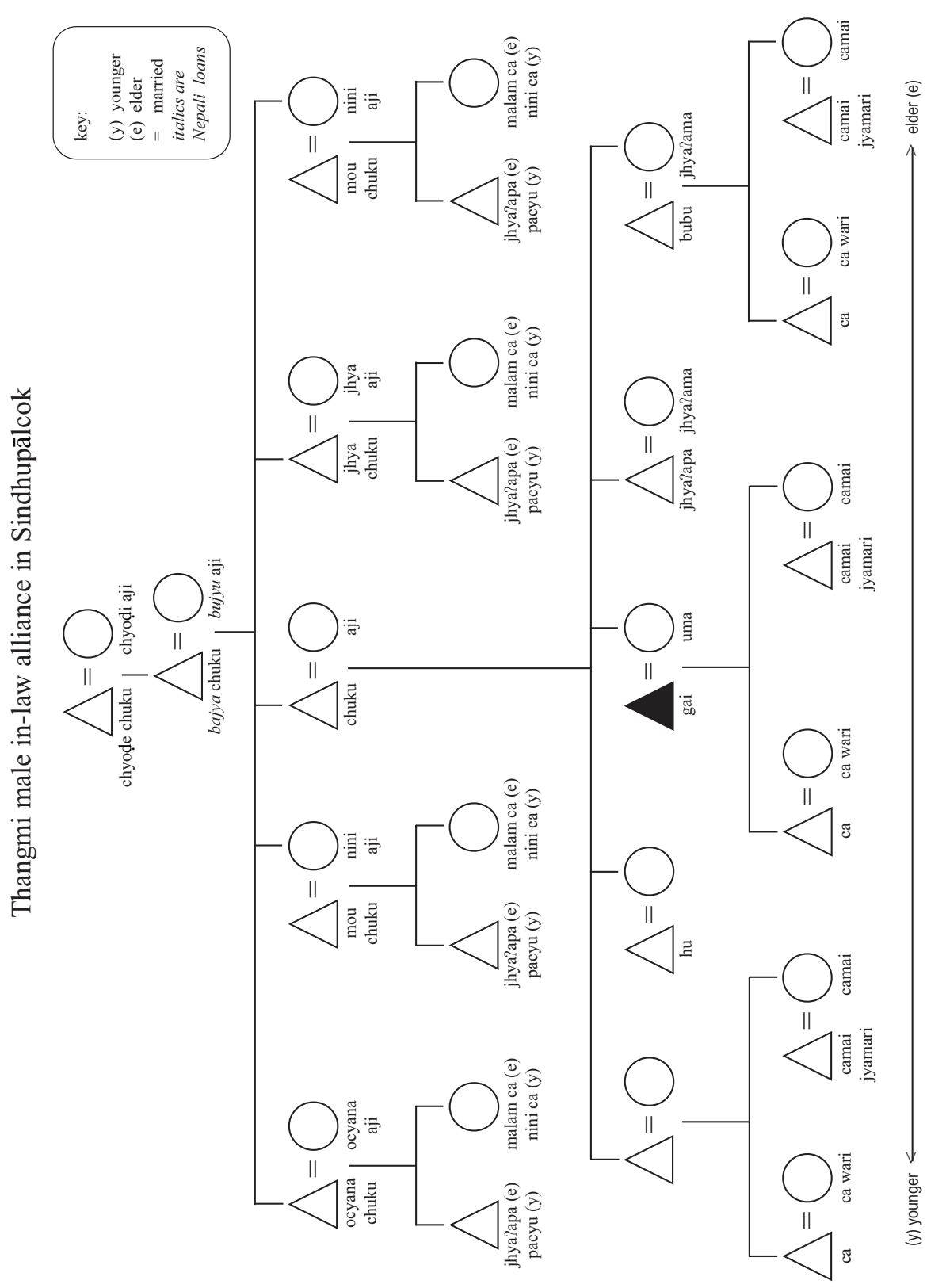




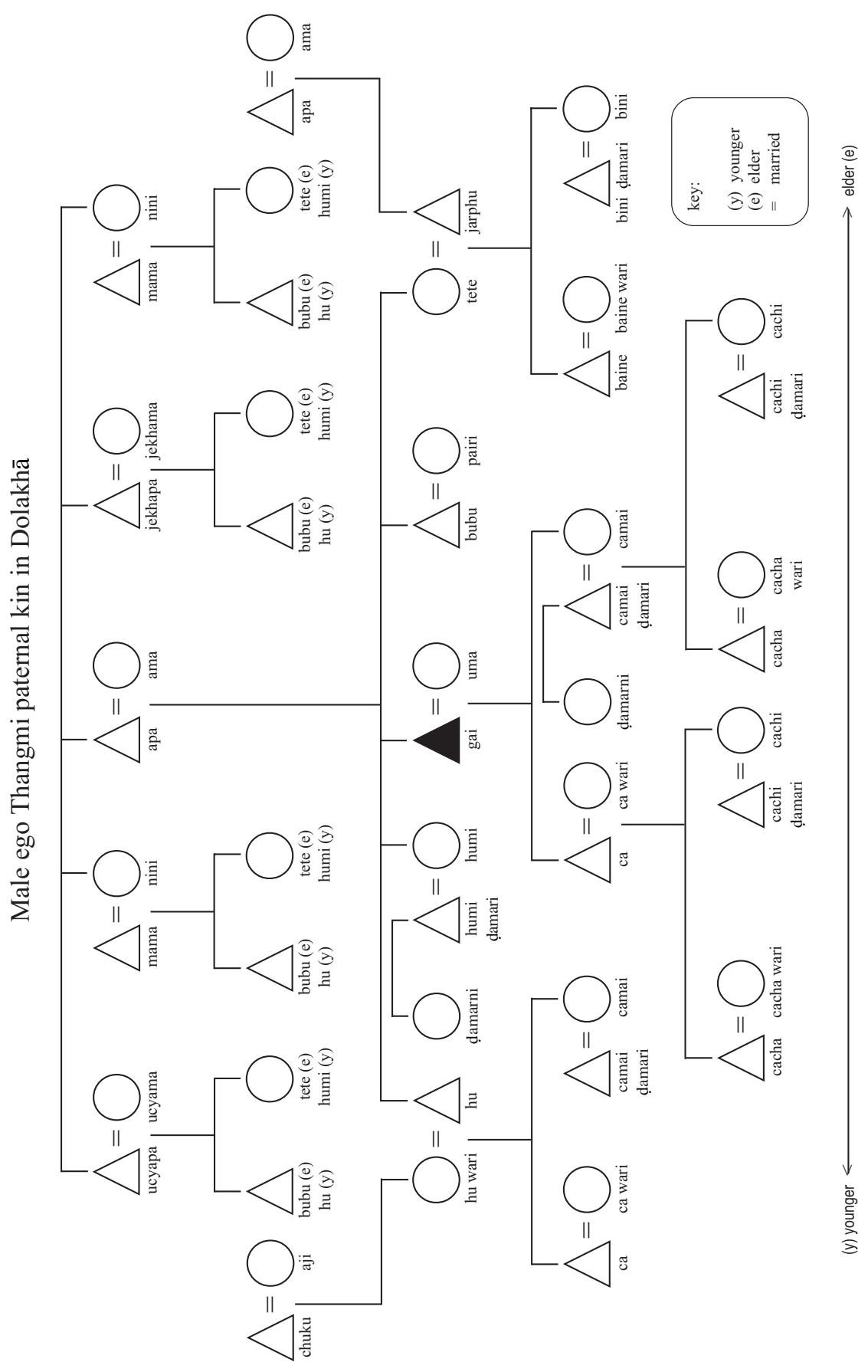




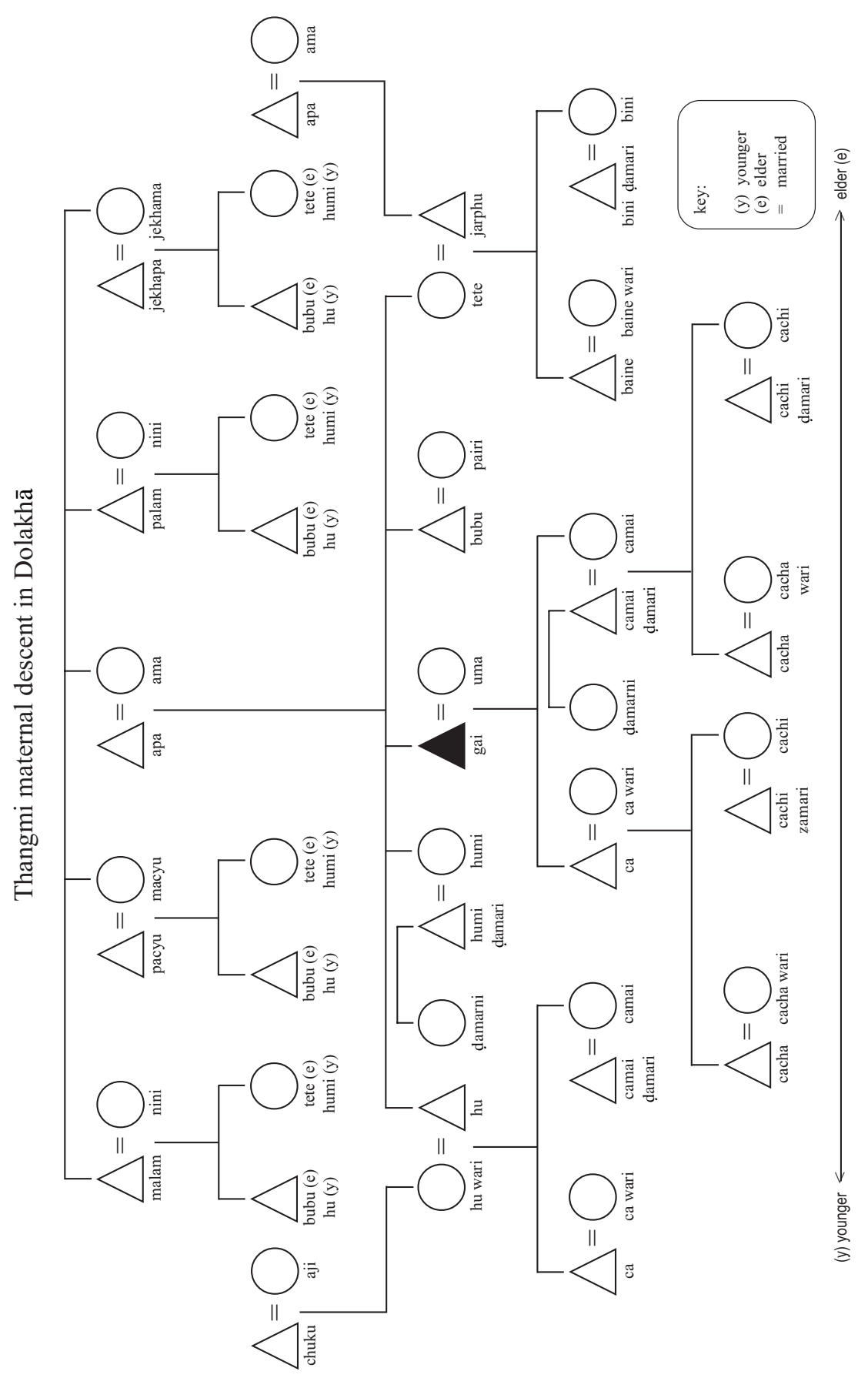




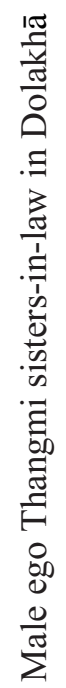

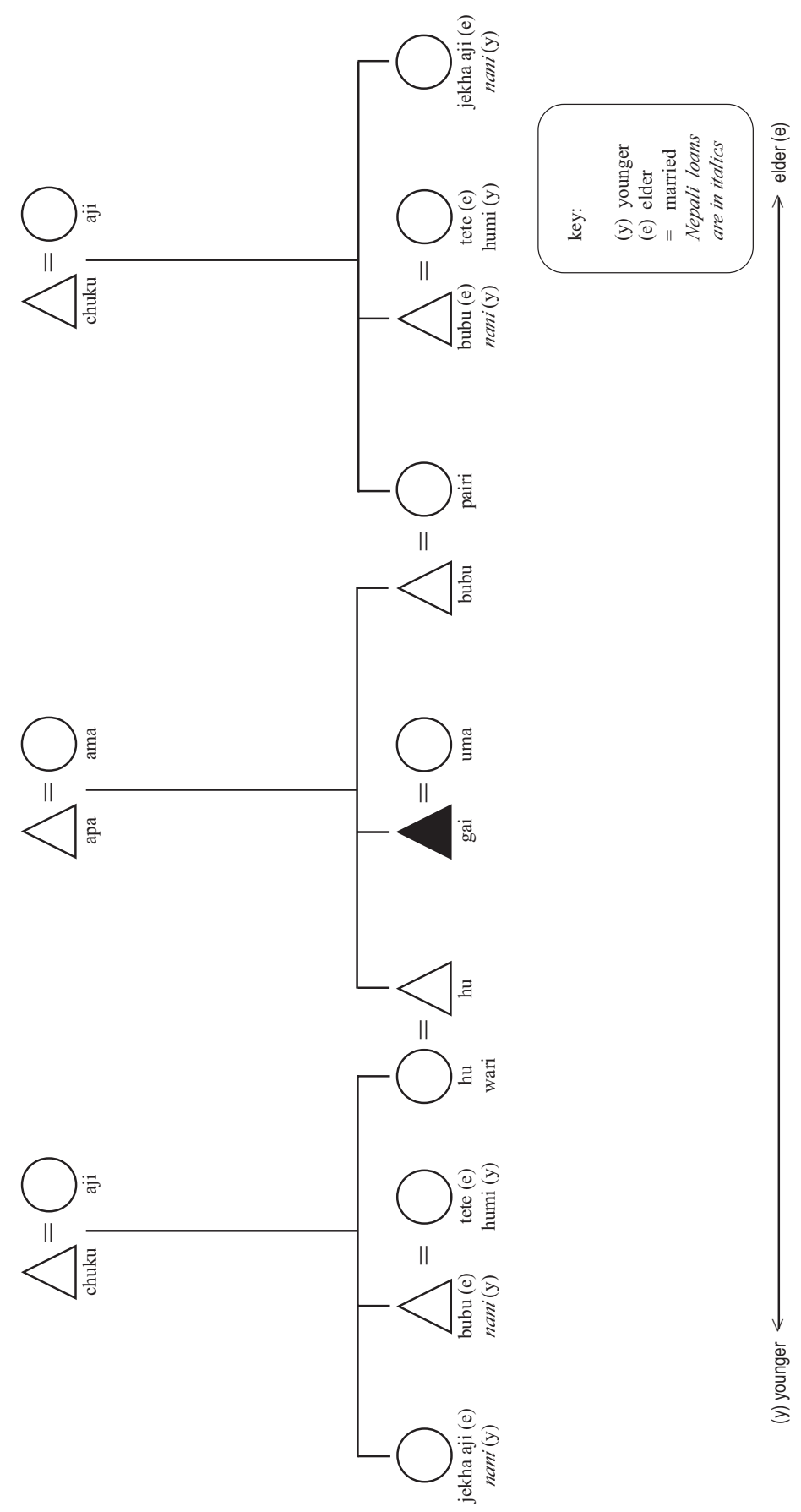




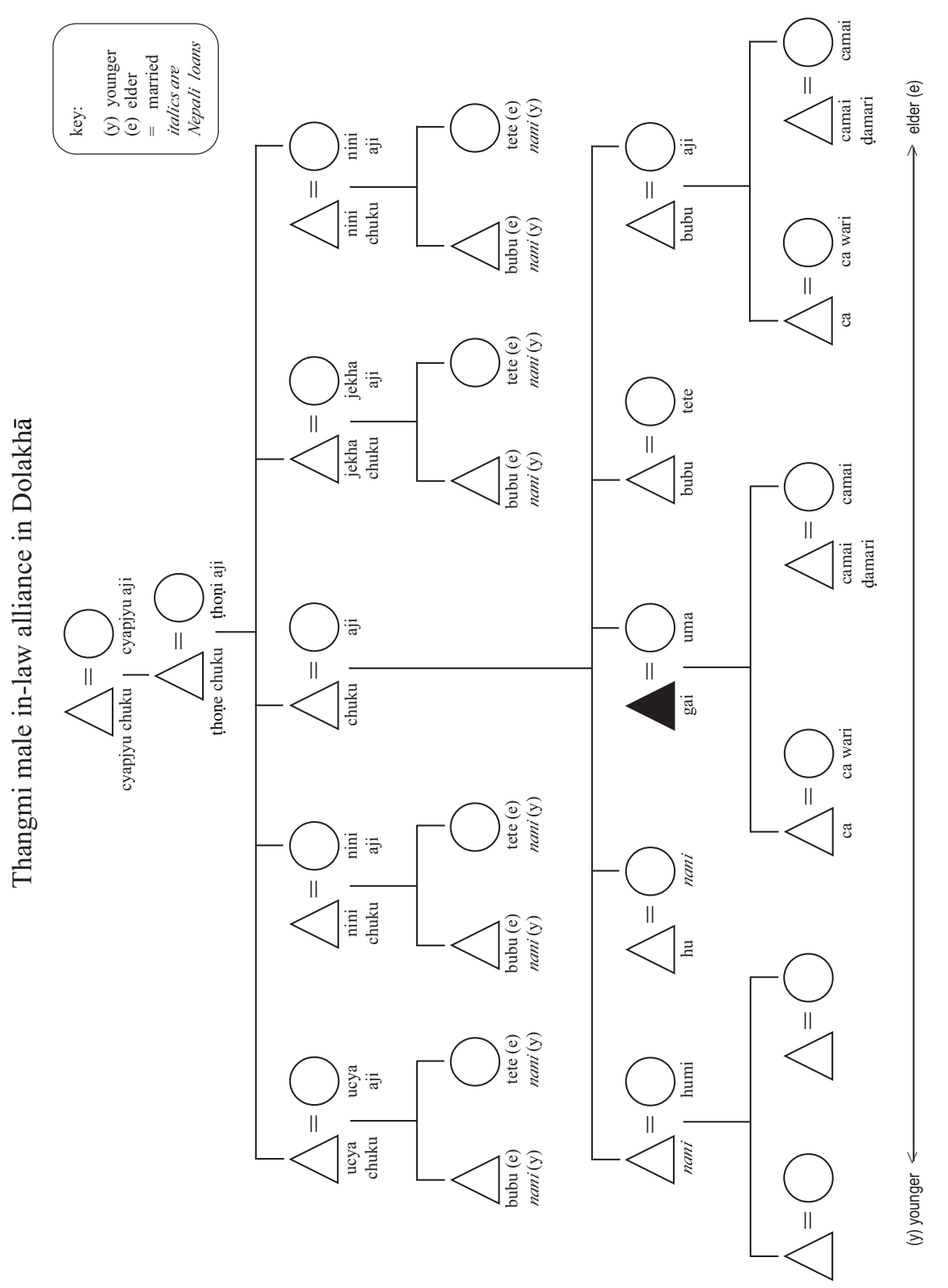




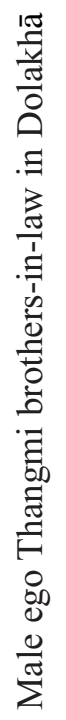

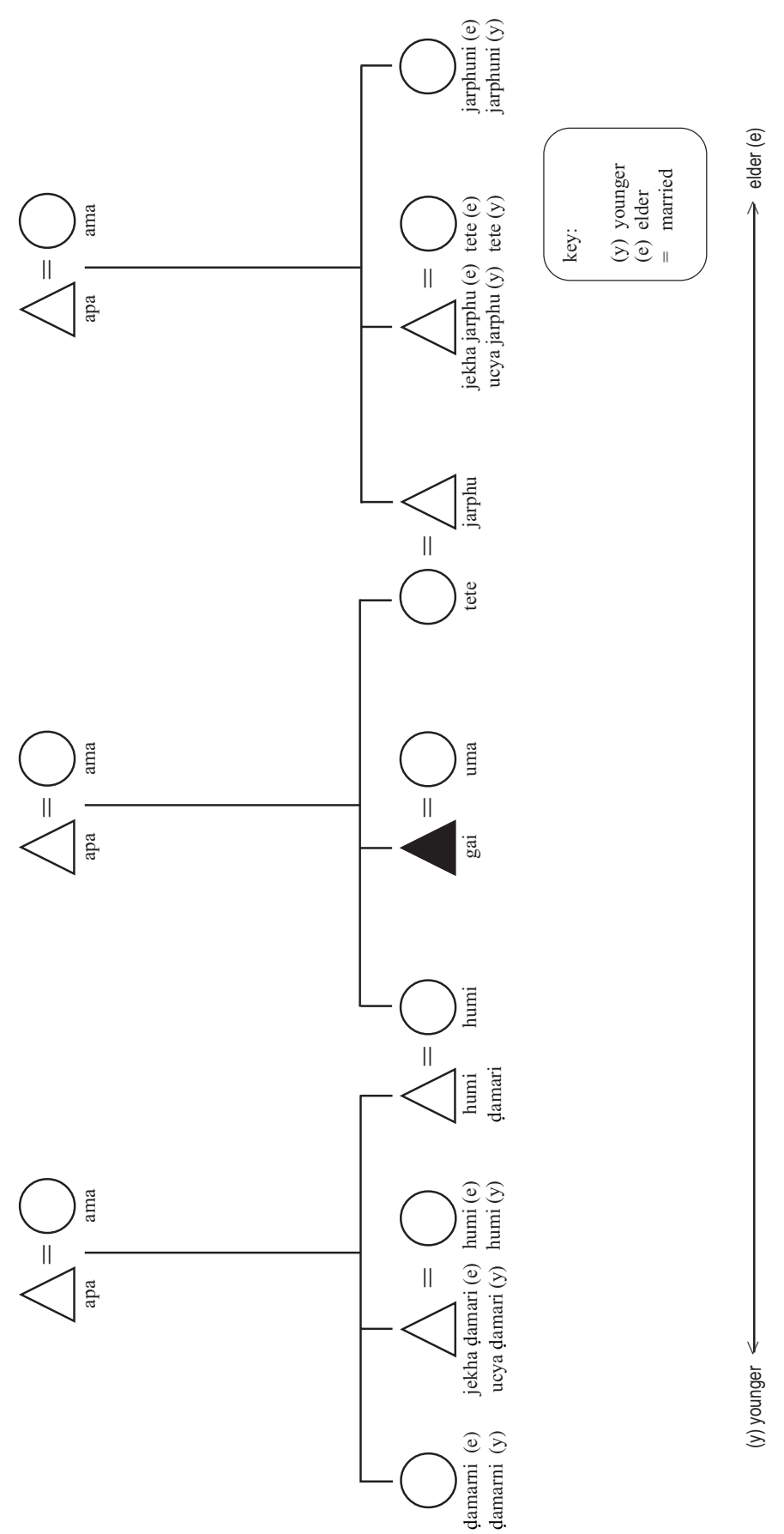




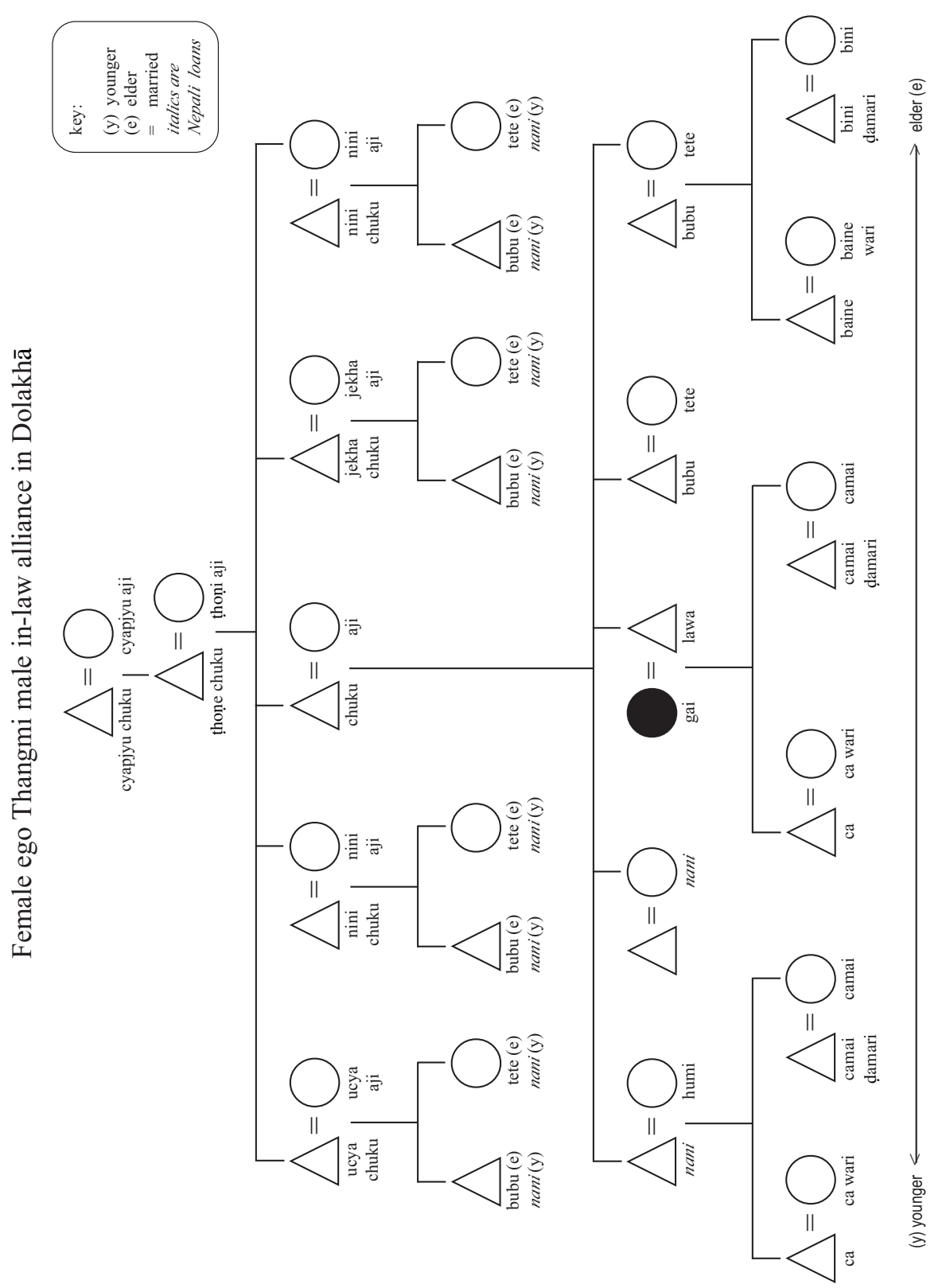




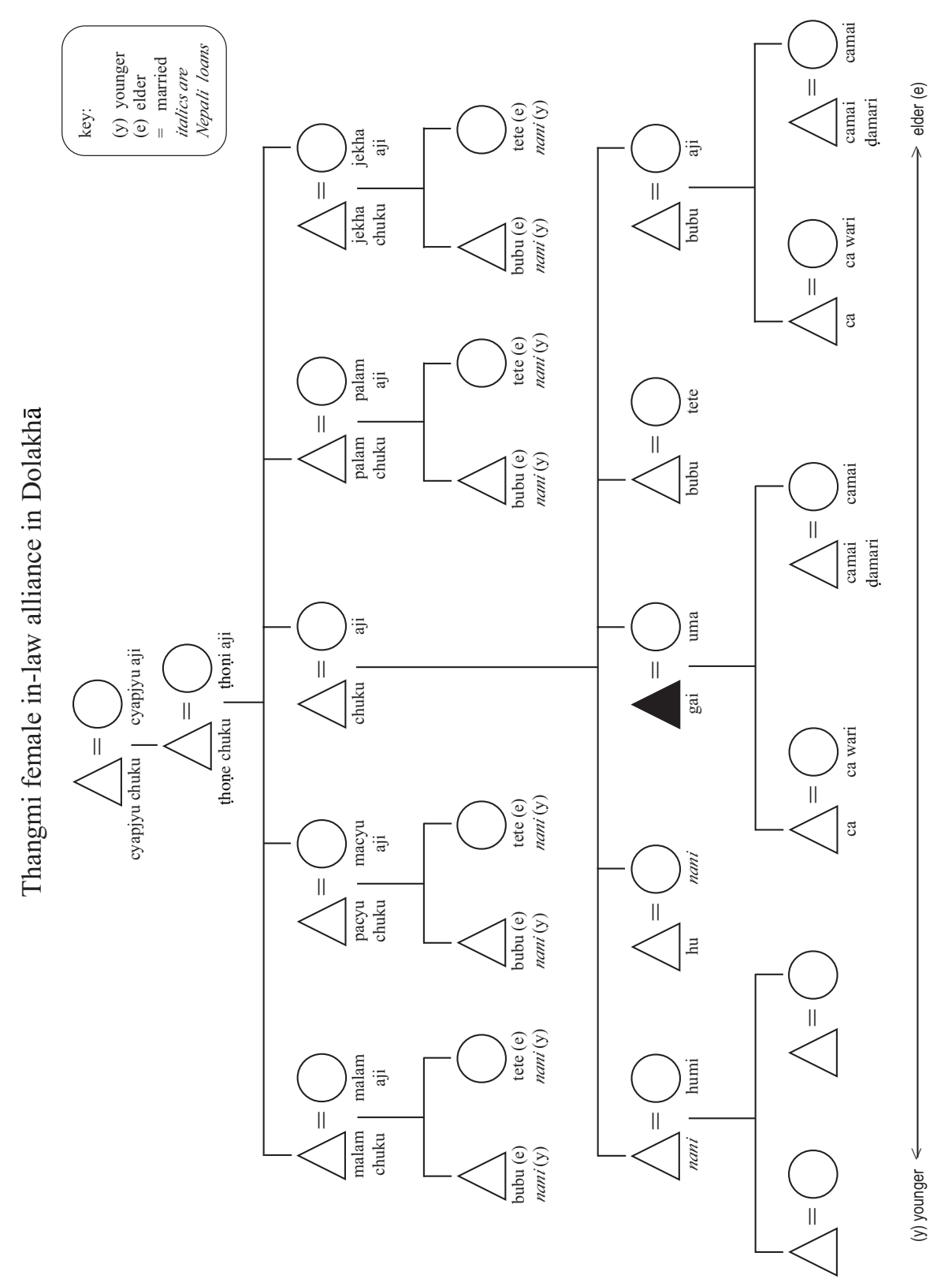




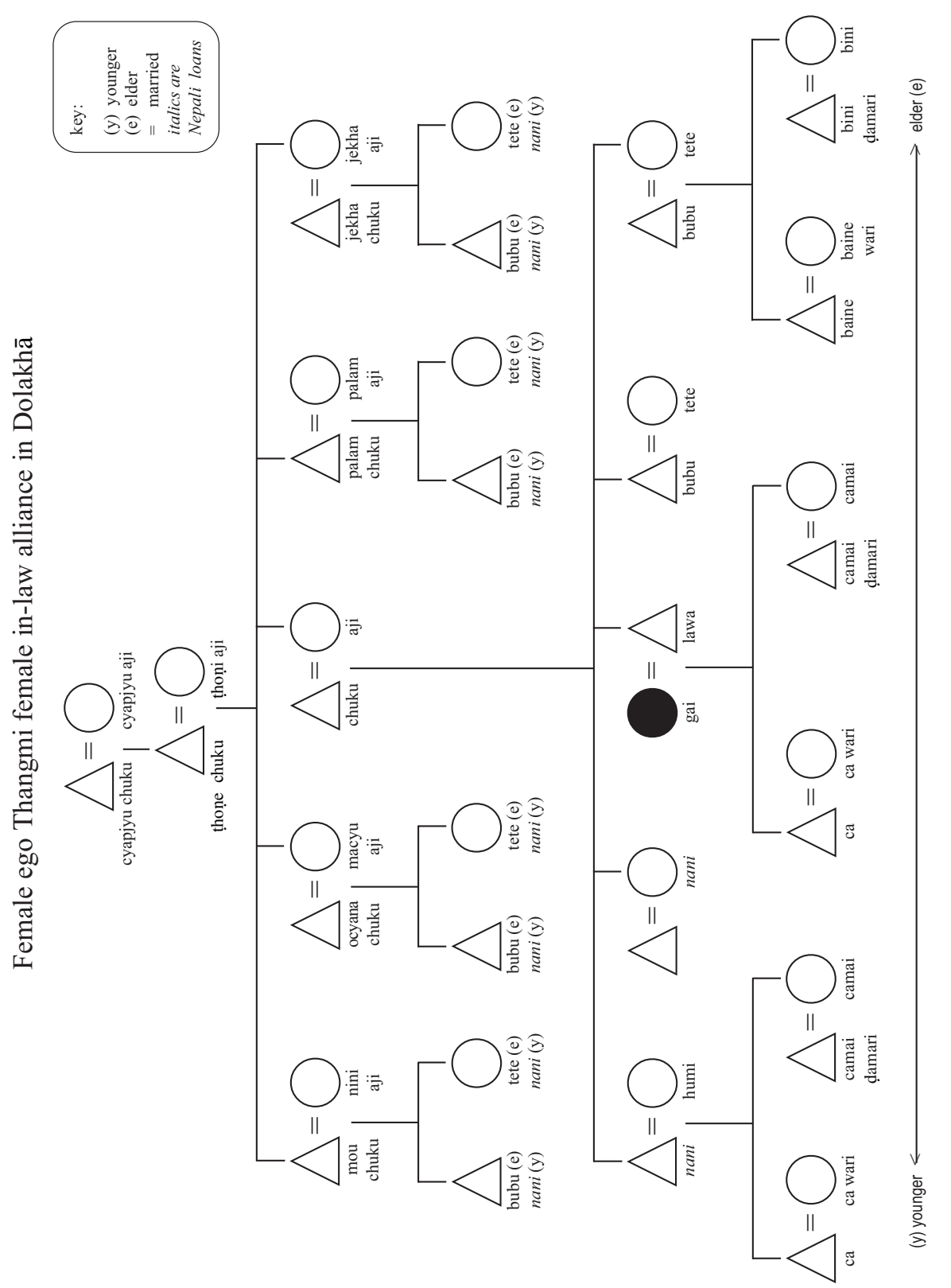




\section{Notes}

1. This paper was presented at the $7^{\text {th }}$ Himalayan Languages Symposium at Uppsala University, Sweden, in September 2001. It has benefited greatly from comments made by participants, particularly by Professor James Matisoff and Dr. Suhnu Ram Sharma. I am grateful to the Research School CNWS at Leiden University in the Netherlands for financial assistance. Without the linguistic insights of Bir Bahādur 'Lile' Thāmī in Nepal, this article could never have been written, and I am thankful for his time and patience. I am also grateful to Sara Shneiderman for her critical editorial eye.

2. In 1999, Subhadra Subba Dahal submitted a three-and-a-half-page article to Nepalese Linguistics entitled 'Thami kinship terms'. The data she presents in her study demonstrate an overwhelming Nepalification of the kinship lexicon, indicating that the speakers with whom she worked were either not fluent in the Thangmi language or from villages close to the market town of Dolakhā. To offer an illustrative example, Dahal records 'father's younger sister's husband' (FySH) as phupažu (Dahal 1999: 10), a Nepali loan, whereas I have attested indigenous Thangmi terms from both dialects: mama 'father's sister's husband' (FSH) in Dolakhā and mou 'father's younger sister's husband' (FySH) in Sindupālcok. Although cursory, Subba's study is worthy of attention as some original data are included.

3. For an in-depth account of female Thangmi clan names see Shneiderman (2000).

4. Aji may well be an early loan into Newar from Sanskrit which has also worked its way into Thangmi.

5. Details of the different interpretations can be found in Shneiderman and Turin (2000).

6. While the Thangmi word guru is manifestly derived from the Sanskrit word guru meaning 'wise man' or 'teacher', Thangmi shamans resolutely claim that the term has its own meaning in their language and indicates a specific group of ritual practitioners. In this much at least, the word is perceived to be indigenous and must be treated as such, as illustrated in Shneiderman (2002).

7. Viewing opposite sex siblings-in-law as akin to one's own brothers and sisters is a distinctly non-Nepali view, given the sexually-charged relations between a man and his wife's younger sister (WyZ) or sāle in Nepali, or a woman and her husband's younger brother (HyB) or dewār.

8. Turin (2002) deals with the intricacies of Nepali kinship terminology with special reference to terms used for foreigners.

9. The same holds true for Nepali, in which $d \bar{a} \bar{\imath}$ 'elder brother' and didī 'elder sister' are commonly used as terms of address for strangers of the same age.

10. Such systems are also attested in Italian, e.g. Primo 'first-born son', Seconda 'second-born daughter' and Terzo 'third-born son'.

11. I have analysed the extensive range of lexical correspondences between Thangmi and Classical Newar in an earlier paper (Turin 2000).

12. The Nepali loan words bāje 'grandfather' and bajyai 'grandmother' are used. 


\section{References}

Allen, Nick

1975 Byansi kinship terminology: A study in symmetry. Man 10: 80-94.

1976 Sherpa kinship terminology in diachronic perspective. Man 11: 569-587.

Benedict, Paul King

1941 Tibetan and Chinese kinship terms. Harvard Journal of Asiatic Studies 6: 313-37.

1972 Sino-Tibetan: A Conspectus. Cambridge: Cambridge University Press.

Burghart, Richard

1975 The role of kinship in the formation of Janakpurdham pilgrim groups. Contributions to Nepalese Studies II (1): 71-90.

Dahal, Subhadra Subba

1999 Thami kinship terms. Nepalese Linguistics 16: 9-12.

Davids, Irene Maria Hendrina and George van Driem

1985 Limbu kinship terminology: A description. Kailash XII (1-2): 115-156.

Doherty, Victor

1974 The organizing principles of Brahmin-Chetri kinship. Contributions

van Driem, George to Nepalese Studies I (2): 25-41.

1987 A Grammar of Limbu. Berlin: Mouton de Gruyter.

1993 A Grammar of Dumi. Berlin: Mouton de Gruyter.

1995 Een eerste grammaticale verkenning van het Bumthang: Een taal van midden-Bhutan. Leiden: Onderzoekschool CNWS.

Glover, Warren, Jessie R. Glover and Deu Bahadur Gurung

1977 Gurung-Nepali-English dictionary, with English-Gurung and NepaliGurung Indexes. (Pacific Linguistics Series C, No. 51.) Canberra: Australian National University.

Hocart, Arthur Maurice

1937 Kinship systems. Anthropos: Internationale Zeitschrift für Völkerund Sprachenkunde XXXII: 545-551.

Jørgensen, Hans

1936 A Dictionary of the Classical Newārī. (Historisk-filologiske Meddelelser) 23 (1). Det Kgl. Danske Videnskabernes Selskab. København: Levin and Munksgaard.

Kroeber, Alfred Louis

1909 Classificatory systems of relationship. Journal of the Royal Anthropological Institute of Great Britain and Ireland XXXIX: 7784.

Malinowski, Bronislaw

1945 The problem of meaning in primitive languages. In The Meaning of Meaning, C. K. Ogden and I. A. Richards (eds.), 296-336. New York/London: Harcourt, Brace \& Company. First published 1923. 
Malla, Kamal Prakash (ed.)

2000 A Dictionary of Classical Newari Compiled from Manuscript Sources. Kathmandu: Nepal Bhasa Dictionary Committee.

McGregor, R. S.

2002 The Oxford Hindi-English Dictionary. Oxford: Oxford University Press.

Pignède, Bernard

1966 Les Gurungs, une population himalayenne du Népal. Paris/The Hague: Mouton \& Co.

Rutgers, Roland

1998 Yamphu: Grammar, Texts and Lexicon. (Languages of the Greater Himalayan Region, No. 2.) Leiden: Research School CNWS.

Shneiderman, Sara

2000 Sisterly clans: A collection of thoughts on Thami women. In Territory and Identity in Tibet and the Himalayas, $\mathrm{K}$. Buffetrille and $\mathrm{H}$. Diemberger (eds.), 233-252. Leiden: Brill.

2002 Embodied ancestors: Territory and the body in Thangmi death rituals. Ādivāsī Mahilā Āvāj (Voice of Indigenous Women) 2 (3): 18-21.

Shneiderman, Sara and Mark Turin

2000 Preliminary etymological notes on Thangmi clan names and indigenous explanations of their provenance. The Journal of Nepalese Literature, Art and Culture 3 (2): 69-83.

Shresthacharya, Iswaranand

1977 Newar kinship terms in the light of kinship typology. Contributions to Nepalese Studies IV (2): 111-128.

Tolsma, Gerard Jacobus

1999 A grammar of Kulung. Ph.D. dissertation, Himalayan Languages Project, Department of Descriptive and Comparative Linguistics, Leiden University.

Turin, Mark

1999 By way of incest and the golden deer: How the Thangmi came to be and the pitfalls of oral history. Journal of Nepalese Studies 3 (1): 13-19.

2000 Shared words, shared history? The case of Thangmi and Late Classical Newar. Nevāḥ Vijñāna, Journal of Newar Studies 3: 9-17.

2002 Call me Uncle: An outsider's experience of Nepali kinship. Contributions to Nepalese Studies XXVIII (2): 277-283.

Vinding, Michael

1979 A preliminary report on kinship terminologies of the Bodish section of Sino-Tibetan speaking peoples. Kailash VII (3-4): 191-225. 